\title{
Alpine endemic spiders shed light on the origin and evolution of subterranean species
}

Stefano Mammola, Marco Isaia, Miquel A Arnedo

We designed a comparative study to unravel the phylogeography of two Alpine endemic spiders characterized by a different degree of adaptation to subterranean life:

Troglohyphantes vignai (Araneae, Linyphiidae) and Pimoa rupicola (Araneae, Pimoidae), the latter showing minor adaptation to hypogean life. We sampled populations of the model species in caves and other subterranean habitats across their known geographical range in the Western Alps. By combining phylogeographic inferences and Ecological Niche Modeling techniques, we infer the biogeographic scenario that led to the present day population structure of the two species. According to our divergent time estimates and relative uncertainties, the isolation of $T$. vignai and $P$. rupicola from their northern sister groups was tracked back to Middle-Late Miocene. Furthermore, the fingerprint left by Pleistocene glaciations on the population structure revealed by the genetic data, led to the hypothesis that a progressive adaptation to subterranean habitats occurred in $T$. vignai, followed by strong population isolation. On the other hand, $P$. rupicola underwent a remarkable genetic bottleneck during the Pleistocene glaciations, that shaped its present population structure. It seems likely that such shallow population structure is both the result of the minor degree of specialization to hypogean life and the higher dispersal ability characterizing this species. The simultaneous study of overlapping spider species showing different levels of adaptation to hypogean life, disclosed a new way to clarify patterns of biological diversification and to understand the effects of past climatic shift on the subterranean biodiversity. 


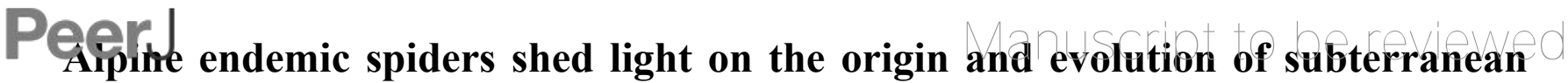 species}

5 Stefano Mammola ${ }^{1}$, Marco Isaia ${ }^{1, *} \&$ Miquel A. Arnedo ${ }^{2}$

1. Department of Life Sciences and Systems Biology, University of Turin, Via Accademia Albertina, 13, 10100, Torino, Italy

10 2. Biodiversity Research Institute and Departament de Biologia Animal, Universitat de Barcelona, Av. Diagonal 643, 08028, Barcelona, Spain

* Corresponding author: marco.isaia@unito.it

Keywords: Comparative phylogeography, Cave-dwelling spiders, Subterranean specialization, DNA markers, Ecological Niche Modeling, Alpine fauna, Pleistocene glaciations, Pimoa, Troglohyphantes, Dispersal

\section{Abstract}

We designed a comparative study to unravel the phylogeography of two Alpine endemic spiders characterized by a different degree of adaptation to subterranean life: Troglohyphantes vignai

25 (Araneae, Linyphiidae) and Pimoa rupicola (Araneae, Pimoidae), the latter showing minor adaptation to hypogean life. We sampled populations of the model species in caves and other subterranean habitats across their known geographical range in the Western Alps. By combining phylogeographic inferences and Ecological Niche Modeling techniques, we infer the biogeographic scenario that led to the present day population structure of the two species. According to our divergent time estimates and relative uncertainties, the isolation of $T$. vignai and P. rupicola from their northern sister groups was tracked back to Middle-Late Miocene. Furthermore, the fingerprint left by Pleistocene glaciations on the population structure revealed by the genetic data, led to the hypothesis that a progressive adaptation to subterranean habitats occurred in $T$. vignai, followed by strong population isolation. On the other hand, $P$. rupicola underwent a remarkable genetic

35 bottleneck during the Pleistocene glaciations, that shaped its present population structure. It seems likely that such shallow population structure is both the result of the minor degree of specialization to hypogean life and the higher dispersal ability characterizing this species. The simultaneous study of overlapping spider species showing different levels of adaptation to hypogean life, disclosed a new way to clarify patterns of biological diversification and to understand the effects of past 40 climatic shift on the subterranean biodiversity. 
Long term climatic changes are often invoked among the most important factors that drove surfacedwelling invertebrate populations to colonize subterranean habitats, causing their isolation and

45 shaping their present day distribution patterns (Jeannel, 1943; Peck, 1980; Holsinger, 1988; Botosaneanu \& Holsinger, 1991; Culver \& Pipan, 2010). In this regard, the Pleistocene glaciations (reviewed in Culver \& Pipan, 2010) and the Messinian Salinity Crisis (Faille et al., 2010) have been pointed out among the main drivers of the present distribution patterns of the European subterranean biodiversity. The climate-driven isolation caused the allopatric divergence of

50 subterranean populations, resulting in narrow patterns of distribution and high levels of endemism (Christman et al., 2005; Culver \& Pipan, 2009; Borges et al., 2012; Cardoso, 2012). Accordingly, population studies conducted so far have uncovered an extreme genetic structuring in terrestrial invertebrates in subterranean habitats (Kane, Barr \& Badaracca, 1992; Allegrucci, Minasi \& Sbordoni, 1997; Gentile \& Sbordoni, 1998; Hedin, 1997; Hedin \& Thomas, 2010; Ribera et al.,

55 2010; Snowman, Zigler \& Hedin, 2010; Dixon \& Zigler, 2011, Zhang \& Li, 2013; see also Bohonak, 1999 for an historical perspective on this topic). This general trend was mainly interpreted in light of the past climatic transitions as the result of the limited dispersal ability of subterranean organisms. Because of the adaptation to the hypogean medium, subterranean species develop narrower physiological tolerance (i.e. troglomorphism sensu Christiansen, 1962), which

60 hamper their dispersal ability through non-subterranean habitats. For example, some cave-dwelling spiders with minor adaptations to hypogean life are known to disperse outside caves in different stages of their life cycle (e.g. Meta spiders; Smithers, 2005; Mammola \& Isaia, 2014). On the other hand, subterranean habitats, especially caves, are generally connected through a networks of small cracks and voids which may facilitate dispersal of the invertebrate fauna (Juberthie et al., 1980,

65 1981; Ueno, 1987; Romero, 2000; Culver \& Pipan, 2009, 2014; Giachino \& Vailati, 2010 among others).

Here we designed a comparative study aimed at providing insights on the origin and the evolution of the hypogean biodiversity. Specifically, we focused on two Alpine endemic species co-occurring in caves and other subterranean habitats across most their distribution range and exhibiting different levels of adaptation to subterranean life.

The first model species, Troglohyphantes vignai Brignoli, 1971 (Araneae, Linyphiidae), is endemic to the Western Italian Alps (NW Italy), being discontinuously distributed from the Cottian (Province of Torino) to the Maritime Alps (Province of Cuneo) (Isaia et al., 2011). Since the 




75 Pesarini, 2001; Arno \& Lana, 2005; Isaia \& Pantini, 2010; Isaia et al., 2011). T. vignai shows adaptations to the hypogean life, namely loss of pigmentation, reduction of the eye apparatus, thinning of integuments and heavy spination. T. vignai was described from the cave Buco di Valenza (Speleological cadastrial number: 1009 Pi/CN; Po Valley) by Brignoli (1971). In the same publication, Brignoli also described T. rupicapra, which was distinguished from T. vignai by small morphological details of the epigynum. T. rupicapra was described on material from Grotta superiore delle Camoscere (Speleological cadastrial number: $250 \mathrm{Pi} / \mathrm{CN}$; Pesio Valley). According to the species description, and as later observed by Isaia et al. (2010, Fig.s 15-18), T. rupicapra shows a higher degree of troglomorphism compared to T. vignai, namely higher depigmentation, reduction of eye diameter and loss of functional eyes, and lowering of the profile of the cephalothorax. The species validity of T. rupicapra was questioned by Pesarini (2001), who proposed the synonymy $T$. rupicapra $=T$. vignai, currently accepted in the World Spider Catalog (2015).

Our second model organism, Pimoa rupicola (Simon, 1884) (Araneae, Pimoidae), is an AlpineApenninic element, recorded almost continuously from the Graian Alps to the Tuscan Apennines

90 (Thaler, 1976; Hormiga, 1994; Isaia et al., 2011) and French Maritime Alps. Several authors (Brignoli, 1971, 1972, 1985; Thaler, 1976; Arnò \& Lana, 2005; Isaia et al., 2011) referred to $P$. rupicola as a troglophile species (sensu Sket, 2008), being abundant in subterranean habitats and occasionally recorded from surface habitats, such as leaf litter, humid rocks covered by mosses and mountain screes (Bertkau, 1890; Jackson, 1926; Thaler, 1976; Hormiga, 1994; Isaia et al., 2014;

95 Isaia, Paschetta \& Chiarle, 2015). Given the sporadic collection of individuals outside cave [mainly pitfall trap data reported in Isaia et al. (2014); Isaia, Paschetta \& Chiarle (2015), and additional unpublished data collected by two of us (SM and MI)], it seems likely that males and immatures of P. rupicola disperse trough the epigean environment. Morphologically, the species does not show any remarkable troglomorphic features: it has eight functional eyes, it is entirely pigmented and it

100 has a well defined abdominal pattern.

To present knowledge (Arnò \& Lana, 2005; Isaia et al., 2011), the Alpine range of P. rupicola encompasses the entire range of $T$. vignai and the two species often co-occur in the same cave.

In this contribution we investigated the biogeographic events that shaped present day population structure of the two species. Since the study was set at the species/population interface, we 105 employed two fast-evolving DNA markers, namely the mitochondrial cytochrome oxidase I (coxl) and the nuclear second internal transcribed spacer region (ITS-2). The popularity of this markers 


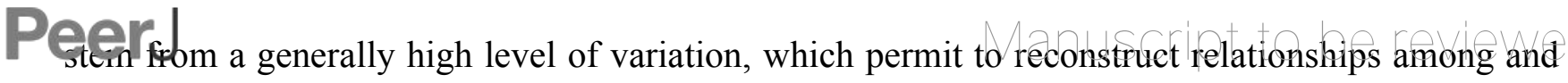
within spider species, making them particularly suitable for population and biogeographic studies (Agnarsson, 2010; Videgar, Toplak \& Kuntner, 2014).

110 Moreover, in accordance with Peterson (2009) we coupled genetic inferences with ecological niche modeling techniques, thus obtaining multiple supports to our research hypothesis. In particular, we hypothesized that past climatic changes played a key role in shaping the genetic structure of the populations of the two species. Given the contrasting degree of subterranean specialization exhibited by the two spiders, we further hypothesized that populations of P. rupicola show minor

115 genetic structure than T. vignai.

Additionally, this study offered the opportunity to reveal the existence of cryptic species within the two lineages. In fact, it was observed during the course of the study that individuals belonging to the northern populations of $P$. rupicola presented subtle but consistent differences in their genital morphology. Hereinafter, we restrict the use of the epithet 'rupicola' to indicate the southern populations, and we will refer tentatively to the northern populations as 'n. sp.'.

\section{Material \& Methods}

\section{Sampling}

125 Populations were collected in caves, abandoned mines and other hypogean habitats across the known distribution range of T. vignai and P. rupicola in the Western Alps. The distribution range of T. vignai was entirely covered (including type locality and former localities of T. rupicapra, indicated hereinafter as T. vignai sensu rupicapra), while for Pimoa we only sampled Alpine populations, thus excluding French and Apenninic populations. The complete list of localities is

130 reported in Tab. 1 and Fig. 1. The toponomastics and classification of the different sectors and subsectors of the Alps follows the partition of the Alpine chain (SOIUSA: Marazzi, 2005). Specimens were hand-collected, preserved in 95\% ethanol and stored in freezer. Given that the sampled environments were highly oligotrophic, in certain localities we were able to detect and collect only few individuals of the two investigated species. The number of individuals collected for each

135 locality ranged from 2 to 8 in $P$. rupicola and $P$. n. sp. and from 1 to 7 in $T$. vignai (Tab. 2). Overall, 119 Pimoa specimens from 25 localities and 37 Troglohyphantes specimens from 8 localities were used in this study. 
146 Gâte4: Summary of the sampled localities.

Manuscript to be reviewed

Sampled localities of Pimoa rupicola, P. n. sp. and Troglohyphantes vignai ordered by latitude (from North to South). Cod: locality numeric code used in the analysis and figures. For each record we report the name of the locality, the name of the Alpine valley, the habitat type, the geographical coordinates (longitude and latitude in decimal degrees, WGS 84 reference system), the date and the

145 collectors. For hypogean localities, we report the Speleological cadastrial number in square brackets [e.g. $1591 \mathrm{Pi} / \mathrm{TO}$ ], when available. An exclamation mark in parenthesis (!) before the name of the locality indicates new unpublished records found during this study.

\begin{tabular}{|c|c|c|c|c|c|c|c|c|c|c|}
\hline Cod & Valley & Locality & Habitat Type & $\mathbf{x}$ & y & P. n.sp & P. rupicola & T. vignai & Date & Collector/s \\
\hline 1 & Susa & (!) Seinera & Abandoned mine & 7,20060 & 45,16314 & * & & & 20.11 .2011 & Mammola S., Piano E., Giuliano D. \\
\hline 2 & Susa & (!) Dravejs & Scree & 7,03913 & 45,11783 & * & & & 13.VI.2014 & Mammola S., Piano E. \\
\hline 3 & Sangonetto & Coazze & Ruined building & 7,24145 & 45,06715 & * & & & 20.II.2011 & Isaia M. \\
\hline 4 & Sangonetto & Garida & Abandoned mine & 7,30394 & 45,05469 & * & & & 20.11 .2011 & Isaia M. \\
\hline 5 & Chisone & [1591 Pi/TO] Tana del Diavolo & Wild cave & 7,12305 & 45,02814 & * & & * & 12.IX.2014 & Isaia M., Mammola S. \\
\hline 6 & Chisone & Bocetto & Abandoned mine & 7,08612 & 44,95900 & * & & & 12.IX.2014 & Isaia M., Mammola S. \\
\hline 7 & Germanasca & [n.c. $\mathrm{Pi} / \mathrm{CN}$ ] Tuna du Diau & Wild cave & 7,10426 & 44,94851 & * & & * & 12.IX.2014 & Isaia M., Mammola S. \\
\hline 8 & Lemina & S. Pietro Val Lemina & Abandoned mine & 7,29650 & 44,93652 & * & & & 12.IX.2014 & Isaia M., Mammola S. \\
\hline 9 & Germanasca & (!) Tornini & Abandoned mine & 7,19887 & 44,90826 & * & & * & 12.IX.2014 & Isaia M., Mammola S. \\
\hline 10 & Germanasca & S. Germano Chisone & Abandoned mine & 7,22477 & 44,90104 & * & & & 13.XI.2014 & Isaia M. \\
\hline 11 & Pellice & [1538 Pi/TO] Gheisa d'la Tana & Wild cave & 7,22365 & 44,85103 & * & & & $28 . I X .2014$ & Isaia M., Mammola S., Paschetta M. \\
\hline 12 & Po & Balma di Rio Martino (Opera 372) & Military bunker & 7,13983 & 44,70178 & * & & & 13.XI.2014 & Isaia M., Mammola S., Paschetta M. \\
\hline 13 & Po & [1148 Pi/CN] Buco del Maestro & Wild cave & 7,23751 & 44,68639 & * & & & $3 . X .2014$ & Isaia M., Mammola S., Paschetta M. \\
\hline 14 & Po & [1009 Pi/CN] Buco di Valenza & Wild cave & 7,17164 & 44,68350 & * & & * & 13.XI.2014 & Isaia M., Mammola S., Paschetta M. \\
\hline 15 & Varaita & (!) Tour Real & Blockhouse & 6,98168 & 44,64500 & * & & & 29.VII.2014 & Mammola S. \\
\hline 16 & Varaita & [1019 Pi/CN] Tana dell'Orso di Casteldelfino & Wild cave & 7,09933 & 44,56082 & & & * & 21.VII.2013 & Mammola S. \\
\hline 17 & Varaita & [1010 Pi/CN] Grotta di Rossana & Wild cave & 7,43131 & 44,53394 & * & & & 20.VII.2013 & Giresi A., Mammola S. \\
\hline 18 & Maira & [n.c. $\mathrm{Pi} / \mathrm{CN}$ ] Grotta del Partigiano di Roccabruna & Wild cave & 7,29424 & 44,50867 & * & & & 14.VII.2014 & Isaia M. \\
\hline 19 & Stura & [1122 Pi/CN] Grotta dello Scoiattolo & Wild cave & 7,38879 & 44,41203 & * & & & 13.I.2015 & Isaia M., Mammola S., Paschetta M. \\
\hline 20 & Stura & [1102 Pi/CN] Buco dell' Aria Calda & Wild cave & 7,46185 & 44,34942 & * & & & 03.X.2014 & Isaia M., Mammola S., Paschetta M. \\
\hline 21 & Stura & [1056 Pi/CN] Grotta della Chiesa di Valloriate & Wild cave & 7,38223 & 44,33940 & * & & & 13.I.2015 & Isaia M., Mammola S., Paschetta M. \\
\hline 22 & Lisio & [884 Pi/CN] Grotta Rio dei Corvi & Wild cave & 7,99383 & 44,30303 & * & & & 26.XII.2014 & Isaia M., Mammola S. \\
\hline 23 & Corsaglia & [113 Pi/CN] Tana di Camplass & Wild cave & 7,88660 & 44,29664 & & * & & 26.XII.2014 & Isaia M., Mammola S. \\
\hline 24 & Vermenagna & Fort (B) of Vernante (Opera 14) & Military bunker & 7,52892 & 44,25736 & & * & & 13.I.2015 & Isaia M., Mammola S., Paschetta M. \\
\hline 25 & Pesio & [250 Pi/CN] Grotta superiore delle Camoscere & Wild cave & - Protec & ted data - & & & * & 26.XII.2014 & Isaia M., Mammola S. \\
\hline 26 & Tanaro & [118 Pi/CN] Grotta dell'Orso di Ponte di Nava & Wild cave & 7,86580 & 44,11904 & & * & & $10 . \times .2014$ & Isaia M., Mammola S. \\
\hline 27 & Tanaro/Ellero & (!) Unknown cave near Colle del Pas & Wild cave & 7,77383 & 44,16597 & & & * & 20.VIII.2014 & Badino G. \\
\hline 28 & Argentina & [619 Li/IM] Sgarbu du ventu & Wild cave & 7,93683 & 44,00206 & & * & & 27.XII.2014 & Isaia M., Mammola S. \\
\hline 29 & Argentina & [104 Li/IM] Tana di Bertrand & Wild cave & 7,86699 & 43,91566 & & * & & 27.XII.2014 & Isaia M., Mammola S. \\
\hline
\end{tabular}

\section{DNA extraction, amplification and sequencing}

One leg was removed from each specimen for DNA extraction. Whole genomic DNA was extracted 155 from the samples using the SpeedTools Tissue Extraction Kit (Biotools) following the manufacturer's protocol. A 676 bp region of the mitochondrial cytochrome oxidase subunit I (coxl) gene and a $400 \mathrm{bp}$ region of the nuclear second internal transcribed spacer region ITS-2 gene were amplified using polymerase chain reaction (PCR). We utilized the primers C1-J-1490 (5'GGTCAACAAATCATAAAGATATTGG-3'; Folmer et al., 1994) and C1-N-2191 (5'-

160 CCCGGTAAAATTAAAATATAAACTTC-3'; Simon et al., 1994) for the coxl and the ITS-5.8s (5'GGGACGATGAAGAACGGAGC-3') and the ITS-28s (5'-TCCTCCGCTTATTGATATGC-3') for the ITS-2 (White et al., 1990). 



Taq polymerase (Promega), $5 \mu \mathrm{L}$ buffer (Promega), $2.25 \mu \mathrm{L} \mathrm{MgCl} 2$ (Promega), $0.2 \mathrm{~mm}$ of each

$165 \mathrm{dNTP}, 0.5 \mu \mathrm{L}$ of each primer and $1.5 \mu \mathrm{L}$ of DNA sample. PCR conditions for amplification were as follows: initial denaturing step at $95^{\circ} \mathrm{C}$ for 5 min, 35 amplification cycles $\left(94{ }^{\circ} \mathrm{C}\right.$ for $30 \mathrm{~s}, 45^{\circ} \mathrm{C}$ for $35 \mathrm{~s}, 72^{\circ} \mathrm{C}$ for $45 \mathrm{~s} \operatorname{cox} 1$ fragment and $94^{\circ} \mathrm{C}$ for $45 \mathrm{~s}, 48^{\circ} \mathrm{C}$ for $1 \mathrm{~min}, 72^{\circ} \mathrm{C}$ for $60 \mathrm{~s}$ for ITS-2 fragment) fallowed by a a final extension at $72^{\circ} \mathrm{C}$ for $5 \mathrm{~min}$. For certain populations of Pimoa rupicola (cave 23 and 26), a slightly different annealing protocol for the $\operatorname{cox} 1$ was utilized $\left(94{ }^{\circ} \mathrm{C}\right.$ for $30 \mathrm{~s}, 42^{\circ} \mathrm{C}$ for $17035 \mathrm{~s}, 72^{\circ} \mathrm{C}$ for $\left.45 \mathrm{~s}\right)$. $\mathrm{PCR}$ products were visualized on agarose gels.

PCR product were cycle-sequenced at Macrogen, Inc. (Seoul, Korea; http://www.macrogen.com). The DNA sequences obtained were preliminary assembled and edited using Geneious 7.1 (Kearse et al., 2012; http://www.geneious.com).

The alignment of the coxl sequences was trivial, as they showed no evidence of indel mutations.

175 The ITS-2 fragments were aligned with the online version of MAFFT (Katoh \& Toh, 2008; http://mafft.cbrc.jp), using the Q-INS-I strategy with default options. We explored best partitioning schemes and substitution models simultaneously using PartitionFinder v.1.0.1 (Lanfear et al., 2012) under a Bayesian information criterion (BIC).

180 Genetic analyses

Population structure

Standard genetic diversity indices (nucleotide and haplotype diversity, A-T bias, transition/transversion rate) were estimated with the PopGenome package (Pfeifer et al., 2014) in R environment ( $\mathrm{R}$ Development Core Team, 2013). We tested for population structure among

185 localities in the coxl dataset using $F_{\mathrm{ST}}$ as implemented in ARLEQUIN 3.01 (Excoffier, Laval \& Schneider, 2005). Significance was assessed by performing 10,000 permutations. We excluded from this analysis six localities (\#1, \#2, \#10,\#15, \#22 and \#27) where the sampling representativeness was questionable (i.e. less than 3 individuals). Haplotype networks were constructed using the statistical parsimony method (Templeton et al., 1992; Clement et al., 2002) with a confidence limit

190 of $95 \%$ as implemented in PopArt (online at: http://popart.otago.ac.nz).

\section{Phylogenetic inference}

Maximum likelihood (ML) and Bayesian inference (BI) were used to infer the gene trees and the concatenated tree for each genus. For this analysis we included unique haplotypes. We concatenated 



ITS-2 were recoded as absence/presence characters using the simple method proposed by Simmons \& Ochoterena (2000) with the help of the computer program SeqState 1.4.1 (Müller, 2005). We used Troglohyphantes nigraerosae and Pimoa edenticulata as outgroups to root the respective trees based on the results of ongoing analyses on the two genera (Arnedo, unpublished data; Hormiga,

200 unpublished data).

ML analyses were performed in RAxML v.7.4.2 (Stamatakis, 2006) with the aid of the graphical interface RAXML-GUI v.1.3 (Silvestro et al., 2011), by conducting 10 runs per 500 bootstrap replicates.

BI analyses were conducted in MrBayes v.3.2 (Ronquist et al., 2012) with two independent runs of

20520 million generations with four Markov chains (one cold, three heated), sampling every 1000 generations. The convergence of chains was checked in Tracer v.1.6 (Rambaut et al., 2014) until effective sample sizes (EES) was above 200, and the average standard deviation of split frequencies (ASDSF) of the two runs was below 0.02 . The first $20 \%$ of trees in each run were discarded as burn-in. The majority-rule consensus tree was generated from remaining trees.

\section{Divergence time estimation}

Divergence time was estimated for the two lineages using a multispecies coalescent approach (Heled \& Drummond, 2010), as implemented in BEAST (Drummond et al., 2012). Coalescent groups within each species were first identified by using the General Mixed Yule Coalescence

215 (GMYC; Fujisawa \& Barraclough, 2013) method and used as a proxy of species in the multicoalescent analyses. GMYC is a clustering method that provides an objective way to delimit putative independent evolutionary lineages (i.e. coalescent groups). For each coxl alignment, we generated a ML tree (see analytical protocol above) and we converted it to an ultrametric tree with the help of PATHd8 (Britton et al., 2007). The GMYC analysis was conducted via the package splits

220 (Ezard, Fujisawa \& Barraclough, 2014) in R, after removing zero-length branches and make the tree fully dichotomous.

For estimating the divergence time of Troglohyphantes and Pimoa lineages, we utilized the best gene partition schemes estimated with PartitionFinder. Because of the lack of reliable calibration points (e.g. fossils, relevant geological or biogeographical events) for any of the two lineages, we

225 relied on informed priors of the substitution rates of the cox 1 , based on available information for spiders (Bidegaray-Baptista \& Arnedo, 2011). Preliminary analyses using a lognormal relaxed clock 



and hence a strict clock was preferred. We set the prior rate parameter of the coxl strict clock to a normal distribution with mean $\pm \mathrm{sd}=0.02 \pm 0.006$. Similarly, we assigned a strict clock prior to the 230 ITS-2 partition. To speed up calculation, we defined a flat prior to the ITS-2 mean rate parameter consisting in a uniform distribution with upper and lower bounds 0.2 and 0.0001 , respectively. We selected a Yule model for the tree prior.

For each species we run three independent MCMC chains for 50 million generations, sampling every 10,000 generations. Convergence of the three chains and correct mixing was assessed in

235 Tracer v.1.6 (Rambaut et al., 2014).

\section{Ecological Niche Modeling}

We relied on ecological niche modeling (hereinafter ENM; see, e.g., Elith et al., 2006) to model the ancestral distribution of the target species. Detailed methodological protocol is provided in the

240 Supplementary Materials 1 . In a first step, we collected all records of the target species available in the literature. We managed to track down 22 localities for Troglohyphantes vignai, most of which clustered together. On the other hand, for Pimoa we recovered 110 localities (61 for Pimoa n. sp. and 49 for P. rupicola), including new unpublished records discovered during the present study. Given the low number of localities for T. vignai, we only inferred the ENM model for the Pimoa

245 lineages. The dataset was corrected for potential spatial autocorrelation and haphazard sampling (Oliveira et al., 2014 and references therein). We obtained present day climatic data (19 'Bioclim variables', see Tab. 1 of Supplementary Materials 1) and altitude a.s.l. from the WorldClim website (www.worldclim.org). We obtained downscaled and calibrated Paleoclimatic data for the Last Glacial Maximum ( 22,000 years ago; hereinafter LGM) from three different simulations available

250 from Global Climate Models (GCMs; Coupled Model Intercomparison Project phase 5; http://cmippcmdi.llnl.gov/cmip5). The climatic preferences of the two species were investigated via Principal Component Analysis (PCA) in the Vegan R package (Oksanen et al., 2013). We investigated collinearity among covariates and obtained a final set of uncorrelated variables [Annual mean temperature (Bio1), Temperature annual range (Bio7) and Mean temperature of the driest quarter 255 (Bio 9)].

We generated presence-only models with the Maximum Entropy Distribution Models available in MaxEnt (Phillips, Anderson \& Schapire, 2006), as implemented in the dismo R package (Hijmans et al., 2014). Firstly, we computed the models on the present climate and on the occurrence points 
Peserinthe $\mathrm{M}$

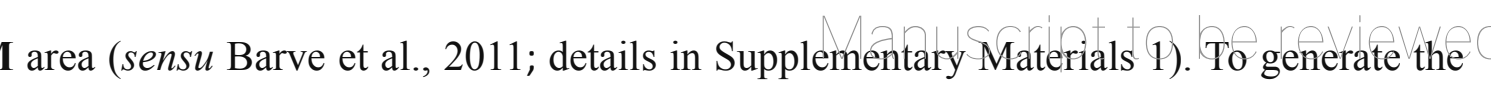
prediction, we ran each niche model 20 times using a loop script in $\mathrm{R}$, keeping in all cases a random partition of $20 \%$ of the occurrence points, which was used to evaluated model performance via the Area Under the Curve (AUC) of the Receiver Operating Characteristic (ROC) plot (Fielding \& Bell, 1997). We projected the MaxEnt models in the LGM climate, under each of the three GCMs climatic scenarios. We used a conservative approach to identify potential Pleistocene refugia: we

265 first applied a threshold of 0.6 to the continuous probability surface of presence estimated after the projection. We then combined the three projections, by sub-sampling only those pixel classified as potentially occupied $(\mathrm{p}>0.6)$ in each LGM forecast.

\section{Results}

270

\section{Population structure}

The new sequences obtained in the present study are available in GenBank (Supplementary Materials 2). A fragment of the mitochondrial cox 1 gene of $676 \mathrm{bp}$ was obtained for 37 specimens of Troglohyphantes vignai in 8 localities, corresponding to 14 unique haplotypes. The cox 1 data set

275 had 79 segregating sites and 9 parsimony informative sites. The overall mean distance ( $p$-distance among haplotypes) was $0.0495 \pm 0.0059$. Sequences of the nuclear intron ITS- 2 were obtained frorm the same individuals. The alignment was 400 positions long, 10 additional absence/presence gap characters were scored, corresponding to 10 ITS-2 sequence types. The ITS-2 had 16 segregating sites and 9 parsimony informative sites. The overall p-distance among caves was $0.0389 \pm 0.0020$.

280 We obtained 676 bp coxl sequence fragments of 119 Pimoa individuals from 25 localities The 93 individuals from 19 localities of Pimoa n. sp. yielded 43 haplotypes (35 segregating sites and 7 parsimony informative sites) and the 27 individuals from 6 localities of P. rupicola yielded 7 haplotypes. The average $p$-distance within populations in Pimoa n. sp. and P. rupicola was $0.0076 \pm 0.0017$ and $0.0052 \pm 0.0017$, respectively, and the maximum $p$-distance between the two

285 lineages was $0.1164 \pm 0.0111$. The nuclear ITS-2 sequences were obtained from 118 Pimoa specimens. The final alignment included 411 positions and 4 additional gap characters. Individuals of Pimoa n. sp. (90 individuals) and P. rupicola (28 individuals) yielded 34 and 10 sequence types, respectively. The average $p$-distance within populations in Pimoa n. sp. and P. rupicola was $0.0102 \pm 0.0027$ and $0.0035 \pm 0.0017$, respectively, and the maximum $p$-distance between the two

290 lineages was $0.0701 \pm 0.0121$. 


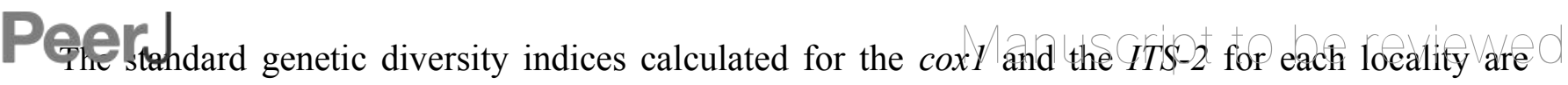
summarized in Tab. 2. Pimoa n. sp. showed high levels of nucleotide diversity and low levels of haplotype diversity in most of the populations, while both P. rupicola and T. vignai showed low levels of haplotype and nucleotide diversity. This pattern was especially obvious in P. rupicola,

295 since most individuals within populations were identical.

Pairwise $F_{\mathrm{ST}}$ values calculated for the localities of the three species are reported in Tab. 3. Pairwise $F_{\mathrm{ST}}$ values between localities revealed contrasting patterns of gene flow. In T. vignai, pairwise $F_{\mathrm{ST}}$ values between localities were always higher than 0.8 , and significant $(\mathrm{p}<0.05)$, except for localities \#14 and \#16. A relatively strong population structure was also found in P. rupicola. 300 Pairwise $F_{\text {ST }}$ values between localities were always higher than 0.6 , although significant comparisons involved exclusively southernmost localities (\#28 and \#29). Pimoa n. sp. showed instead a more shallow population structure, with several $F_{\mathrm{ST}}$ values below 0.5 , generally corresponding to nearby localities.

305

310 
32 Pẫरी: genetic diversity indices.

Diversity measures for the coxl and ITS-2 genes for the localities of Pimoa n. sp., P. rupicola and Troglohyphantes vignai sampled in this study. $\mathbf{N}=$ number of individuals; $\mathbf{H}=$ number of haplotypes; $\mathbf{I}=$ nucleotide diversity; $\mathbf{h}=$ haplotype diversity. Populations of $T$. vignai sensu rupicapra are indicated with an asterisks $(*)$.

330

\begin{tabular}{|c|c|c|c|c|c|c|c|c|c|}
\hline \multirow[b]{2}{*}{ Locality code } & \multirow[b]{2}{*}{ Species } & \multicolumn{4}{|c|}{ Cox1 } & \multicolumn{4}{|c|}{ ITS-2 } \\
\hline & & $\mathbf{N}$ & $\mathbf{H}$ & $\pi$ & $\mathrm{h}$ & $\mathbf{N}$ & $\mathbf{H}$ & $\pi$ & $\mathbf{h}$ \\
\hline 1 & P. n.sp. & 2 & 2 & 1,000 & 1,000 & 2 & 1 & 0,000 & 0,000 \\
\hline 2 & P. n.sp. & 2 & 2 & 1,000 & 1,000 & 2 & 1 & 0,000 & 0,000 \\
\hline 3 & P. n.sp. & 5 & 2 & 0,600 & 0,600 & 5 & 2 & 0,400 & 0,400 \\
\hline 4 & P. n.sp. & 4 & 1 & 0,000 & 0,000 & 2 & 1 & 0,000 & 0,000 \\
\hline 5 & P. n.sp. & 8 & 1 & 0,000 & 0,000 & 6 & 2 & 0,476 & 0,476 \\
\hline 6 & P. n.sp. & 6 & 1 & 0,000 & 0,000 & 6 & 1 & 0,000 & 0,000 \\
\hline 7 & P. n.sp. & 7 & 2 & 0,285 & 0,285 & 7 & 1 & 0,000 & 0,000 \\
\hline 8 & P. n.sp. & 3 & 3 & 0,000 & 0,000 & 3 & 2 & 0,666 & 0,666 \\
\hline 9 & P. n.sp. & 6 & 3 & 2,133 & 0,533 & 6 & 3 & 1,400 & 0,600 \\
\hline 10 & P. n.sp. & 2 & 1 & 0,000 & 0,000 & 2 & 1 & 0,000 & 0,000 \\
\hline 11 & P. n.sp. & 4 & 4 & 5,666 & 1,000 & 5 & 3 & 1,333 & 0,666 \\
\hline 12 & P. n.sp. & 7 & 4 & 2,476 & 0,714 & 8 & 3 & 0,678 & 0,464 \\
\hline 13 & P. n.sp. & 8 & 5 & 2,429 & 0,857 & 8 & 3 & 1,047 & 0,523 \\
\hline 14 & P. n.sp. & 5 & 2 & 1,500 & 0,500 & 5 & 2 & 0,333 & 0,333 \\
\hline 15 & P. n.sp. & 2 & 1 & 0,000 & 0,000 & 2 & 1 & 0,000 & 0,000 \\
\hline 17 & P. n.sp. & 5 & 2 & 2,500 & 0,500 & 4 & 1 & 0,000 & 0,000 \\
\hline 18 & P. n.sp. & 5 & 2 & 0,666 & 0,333 & 5 & 1 & 0,000 & 0,000 \\
\hline 19 & P. n.sp. & 3 & 3 & 2,666 & 0,666 & 3 & 2 & 0,000 & 0,000 \\
\hline 20 & P. n.sp. & 4 & 1 & 0,000 & 0,000 & 4 & 2 & 0,500 & 0,500 \\
\hline 21 & P. n.sp. & 5 & 1 & 0,000 & 0,000 & 5 & 1 & 0,000 & 0,000 \\
\hline 22 & P. rupicola & 2 & 1 & 0,000 & 0,000 & 2 & 1 & 0,000 & 0,000 \\
\hline 23 & P. rupicola & 5 & 1 & 0,000 & 0,000 & 5 & 1 & 0,000 & 0,000 \\
\hline 24 & P. rupicola & 4 & 1 & 0,000 & 0,000 & 5 & 1 & 0,000 & 0,000 \\
\hline 26 & P. rupicola & 6 & 1 & 0,000 & 0,000 & 6 & 1 & 0,000 & 0,000 \\
\hline 28 & P. rupicola & 7 & 1 & 0,000 & 0,000 & 7 & 5 & 2,285 & 0,857 \\
\hline 29 & P. rupicola & 3 & 2 & 7,333 & 0,667 & 3 & 1 & 0,000 & 0,000 \\
\hline 5 & T. vignai & 6 & 2 & 0,612 & 0,600 & 6 & 1 & 0,000 & 0,000 \\
\hline 6 & T. vignai & 6 & 2 & 1,000 & 0,500 & 6 & 3 & 1,166 & 0,833 \\
\hline 7 & T. vignai & 5 & 1 & 0,000 & 0,000 & 5 & 1 & 0,000 & 0,000 \\
\hline 9 & T. vignai & 7 & 3 & 0,571 & 0,523 & 7 & 1 & 0,000 & 0,000 \\
\hline 14 & T. vignai & 3 & 1 & 0,000 & 0,000 & 3 & 1 & 0,000 & 0,000 \\
\hline 16 & T. vignai & 3 & 1 & 0,000 & 0,000 & 3 & 1 & 0,000 & 0,000 \\
\hline 25 & T. vignai * & 6 & 3 & 0,666 & 0,600 & 6 & 1 & 0,000 & 0,000 \\
\hline 27 & T. vignai * & 1 & 1 & 0,000 & 0,000 & 1 & 1 & 0,000 & 0,000 \\
\hline
\end{tabular}


346 Ga.les: population structure among localities

\section{Manuscript to be reviewed}

$F_{\mathrm{ST}}$ values for mtDNA coxl of Pimoa n. sp., P. rupicola and Troglohyphantes vignai based on the Tamura and Nei model. Locality codes are explained in Tab. 1. Values in bold represent significant comparisons $(\mathrm{p}<0.05)$. Localities \#1, \#2, \#10,\#15, \#22 and \#27 were excluded from the analysis, being represented by less than three individuals.

\begin{tabular}{|c|c|c|c|c|c|c|c|c|c|c|c|c|c|c|c|c|}
\hline \multicolumn{17}{|c|}{$F_{\mathrm{ST}}$ Pimoa n.sp. } \\
\hline & 3 & 4 & 5 & 6 & 7 & 8 & 9 & 11 & 12 & 13 & 14 & 17 & 18 & 19 & 20 & 21 \\
\hline 3 & 0,000 & - & - & - & - & - & - & - & - & - & - & - & - & - & - & - \\
\hline 4 & 0,250 & 0,000 & - & - & - & - & - & - & - & - & - & - & - & - & - & - \\
\hline 5 & 0,723 & 0,018 & 0,000 & - & - & - & - & - & - & - & - & - & - & - & - & - \\
\hline 6 & 0,787 & 0,123 & 0,332 & 0,000 & - & - & - & - & - & - & - & - & - & - & - & - \\
\hline 7 & 0,557 & 0,322 & 0,412 & 0,341 & 0,000 & - & - & - & - & - & - & - & - & - & - & - \\
\hline 8 & 0,700 & 0,764 & 0,597 & 0,422 & 0,857 & 0,000 & - & - & - & - & - & - & - & - & - & - \\
\hline 9 & 0,433 & 1,000 & 0,733 & 0,733 & 0,590 & 0,733 & 0,000 & - & - & - & - & - & - & - & - & - \\
\hline 11 & 0,200 & 1,000 & 0,500 & 0,500 & 0,357 & 0,500 & 0,230 & 0,000 & - & - & - & - & - & - & - & - \\
\hline 12 & 0,340 & 0,561 & 0,642 & 0,642 & 0,500 & 0,642 & 0,376 & 0,142 & 0,000 & - & - & - & - & - & - & - \\
\hline 13 & 0,289 & 0,642 & 0,589 & 0,578 & 0,446 & 0,589 & 0,322 & 0,006 & 0,218 & 0,000 & - & - & - & - & - & - \\
\hline 14 & 0,500 & 0,589 & 0,800 & 0,800 & 0,657 & 0,800 & 0,533 & 0,300 & 0,442 & 0,357 & 0,000 & - & - & - & - & - \\
\hline 17 & 0,450 & 1,000 & 0,750 & 0,750 & 0,607 & 0,750 & 0,483 & 0,250 & 0,392 & 0,186 & 0,470 & 0,000 & - & - & - & - \\
\hline 18 & 0,533 & 0,750 & 0,833 & 0,830 & 0,690 & 0,833 & 0,566 & 0,333 & 0,476 & 0,422 & 0,633 & 0,583 & 0,000 & - & - & - \\
\hline 19 & 0,366 & 0,860 & 0,660 & 0,666 & 0,523 & 0,666 & 0,400 & $-0,071$ & 0,309 & 0,107 & 0,466 & 0,416 & 0,500 & 0,000 & - & - \\
\hline 20 & 0,700 & 1,000 & 1,000 & 1,000 & 0,857 & 1,000 & 0,733 & 0,250 & 0,642 & 0,452 & 0,800 & 0,750 & 0,833 & 0,000 & 0,000 & - \\
\hline 21 & 0,800 & 1,000 & 1,000 & 1,000 & 0,857 & 1,000 & 0,733 & 0,500 & 0,642 & 0,452 & 0,750 & 0,000 & 0,833 & 0,666 & 1,000 & 0,000 \\
\hline \multicolumn{6}{|c|}{$F_{\text {ST Pimoa rupicola }}$} & \multicolumn{9}{|c|}{$F_{\mathrm{ST}}$ Troglohyphantes vignai } & & \\
\hline & 23 & 24 & 26 & 28 & 29 & & & 5 & 6 & 7 & 9 & 14 & 16 & 25 & & \\
\hline 23 & 0,000 & - & - & - & - & & 5 & 0,000 & - & - & - & - & - & - & & \\
\hline 24 & 1,000 & 0,000 & - & - & - & & 6 & 0,916 & 0,000 & - & - & - & - & - & & \\
\hline 26 & 1,000 & 1,000 & 0,000 & - & - & & 7 & 0,964 & 0,855 & 0,000 & - & - & - & - & & \\
\hline 28 & 1,000 & 0,667 & 1,000 & 0,000 & - & & 9 & 0,957 & 0,873 & 0,943 & 0,000 & - & - & - & & \\
\hline \multirow[t]{3}{*}{29} & 0,876 & 0,876 & 0,876 & 0,667 & 0,000 & & 14 & 0,991 & 0,988 & 1,000 & 0,991 & 0,000 & - & - & & \\
\hline & & & & & & & 16 & 0,989 & 0,984 & 1,000 & 0,989 & 1,000 & 0,000 & - & & \\
\hline & & & & & & & 25 & 0,987 & 0,984 & 0,992 & 0,988 & 0,975 & 0,988 & 0,000 & & \\
\hline
\end{tabular}

Pimoa haplotypes were resolved as two independent networks, corresponding to Pimoa n. sp. (1) and P. rupicola (2), respectively, separated by 42 steps. P. rupicola haplotypes were limited to single populations, except H26 and H27, which were shared across populations. Generally, populations had low haplotype diversity, and in one case (\#26) there was one single haplotype. Two divergent haplotypes (11 steps), however, were found in locality \#29.

In Pimoa n. sp. haplotypes from nearby localities clustered together or were separated by only few steps (1-4). Several haplotypes (H7, H8, H12, H14) were shared among closely located localities (e.g. occurring in the same Alpine valley or in adjacent valleys). In some instances, however,

355 haplotypes from distant localities were found to be very similar (few steps), e.g. locality \#1 and \#2 with \#12. Moreover, two haplotypes (H18 and H22) were found in individuals occurring in distant populations.

In $T$. vignai, haplotypes were not shared between localities. Haplotypes from closely located populations were generally separated by few mutations. Haplotype diversity was low within 360 populations, and localities \#7,\#14 and \#16 showed single haplotypes. Two localities (\#9 and \#25), on the other hand, had more than two haplotypes. The haplotypes of T. vignai sensu rupicapra were 


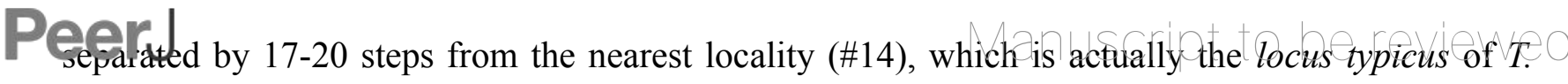
vignai (Buco di Valenza cave). A higher number of steps (38-56) separated this cave from the remaining localities.

\section{Phylogenetic tree and estimation of the divergent time}

Partition Finder selected the full codon as the best partition scheme for the alignments of both species. The models for each partition are reported in the Tab. 2 of Supplementary Materials 1. Both the Bayesian and ML analyses of the concatenated data matrix of T. vignai yielded in similar tree

370 topologies, and most branches were highly supported [i.e. posterior probabilities (PP) $>0.95$, bootstrap support (BS) $>75 \%$; Fig. 2]. T. vignai was split in two main clades: one including the southern populations (\#14, \#16,\#25 and \#27), and the second one including the remaining northern populations (\#5,\#6, \#7 and \#9). The Bayesian and the ML analyses also recovered similar tree topologies in Pimoa (Fig. 3). Two well-supported clades were detected, corresponding to Pimoa $\mathrm{n}$.

375 sp. and P. rupicola, respectively. Individuals from geographical adjacent localities were closely related, although basal branches within Pimoa n. sp. were poorly supported. 

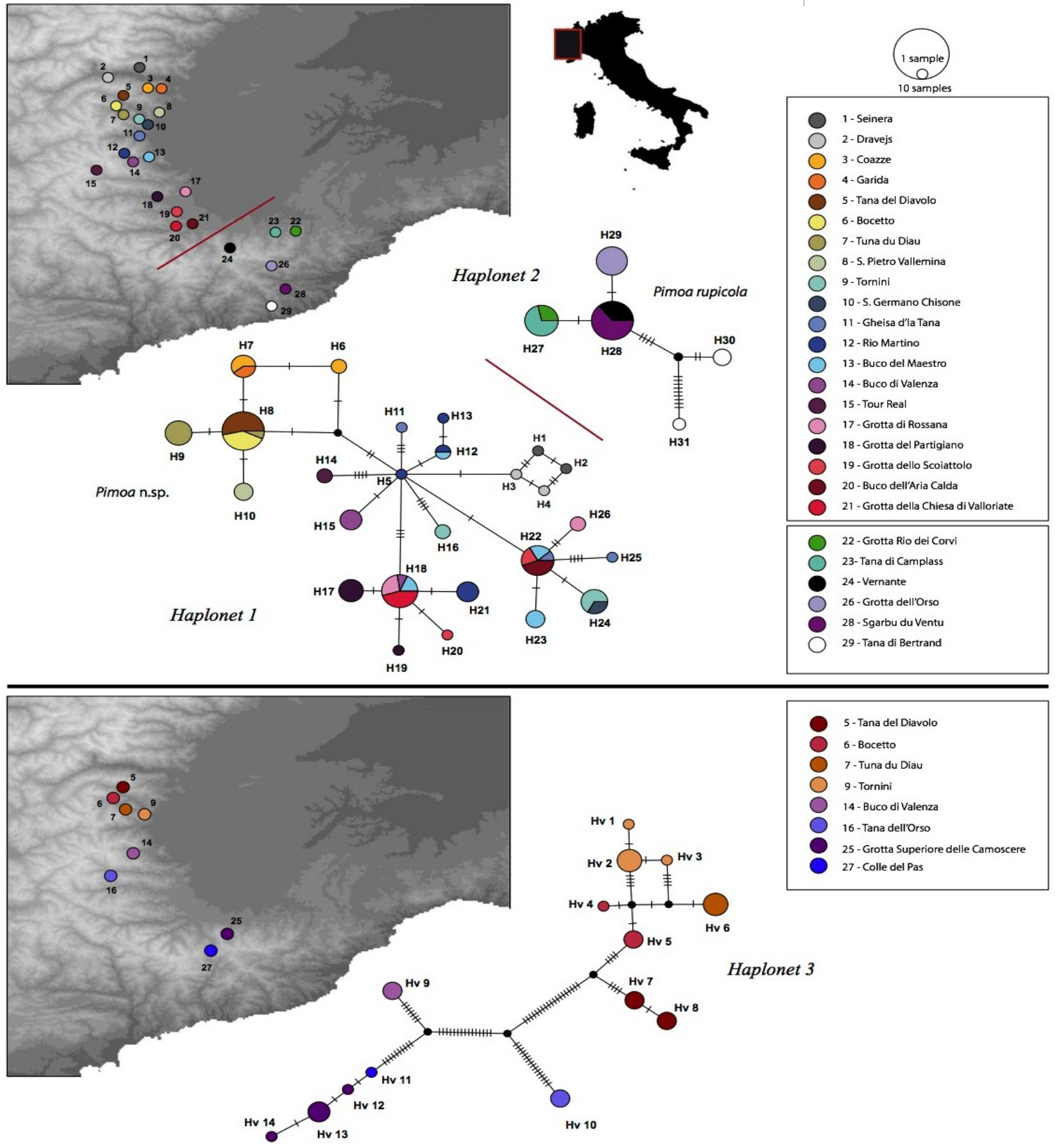

5 - Tana del Diavolo
6 - Bocetto
7 - Tuna du Diau
9 - Tornini
14 - Buco di Valenza
16 - Tana dellorso
25 - Grotta Superiore delle Camoscere
27 - Colle del Pas

\section{Figure 1: haplotype networks of the investigated populations.}

Statistical parsimony haplonetworks for Pimoa n. sp. (Haplonet 1 - upper panel), P. rupicola (Haplonet 2 - upper panel) and Trogolohyphantes vignai (Haplonet 3 - lower panel). Numbers in maps indicate localities (see legend), alphanumeric codes in the networks refer to haplotypes. The size of each circle is proportional to the number of sampled individuals with each haplotype (see scale above the legend). Unsampled and/or extinct haplotypes are represented by small black circles. 




Figure 2: phylogenetic tree of Troglohyphantes.

405 Topology obtained in the concatenated Bayesian analysis for Troglohyphantes vignai. Only one individual per haplotype is shown. Vertical rectangles denote support as follows: Bayesian posterior probabilities (PP; left rectangles) and maximum likelihood bootstraps (ML; right rectangles); black: PP $>0.95$, ML bootstrap support $>70 \%$, white: support values lower than threshold values. The asterisk (*) indicate the locus typicus of T. vignai. Localities \#25 and \#27 refer to T. vignai sensu rupicapra. 




\section{Figure 3: Phylogenetic tree of Pimoa.}

Topology obtained in the concatenated Bayesian analysis for Pimoa. Only one individual per haplotype is shown. Vertical rectangles denote support as follows: Bayesian posterior probabilities

425 (PP; left rectangles) and maximum likelihood bootstraps (ML; right rectangles); black: PP > 0.95, ML bootstrap support $>70 \%$, white: support values lower than threshold values. 



100.8932; LR= 28.59767; $\mathrm{p}<0.000)$, one including all sequences/localities of P. rupicola and the other including all sequences/localities of Pimoa n. sp. Troglohyphantes vignai coxl sequences 435 were resolved as 7 coalescent clusters $(M L=424.2824$; $L R=207.4615$; $p<0.000$; Fig. 4). Except for cluster A2, which included individuals from two caves, each cluster corresponded to individuals sampled from single caves.

The species trees and the imbedded coxl gene tree recovered for each spider genus are shown in Fig. 4. The substitution rate estimated for the Troglohyphantes cox 1 was 0.0218 substitutions per 440 lineage/million years $(95 \% \mathrm{HPD}=0.010-0.033)$, and for the ITS-2 was $0.0024(95 \% \mathrm{HPD}=0.0005-$ 0.0031). The split between T. vignai and T. nigraerosae was traced back to approximately 7.2 million years ago (Ma, 95\% Highest Posterior Density, HPD=13.7-3.5 Ma). Diversification of the extant T. vignai lineages occurred 2.9 million years ago $(95 \% \mathrm{HPD}=5.4-1.5 \mathrm{Ma})$, while the diversification of the extant northern populations (D2, E2, F2, G2 clusters) occurred approximately

445 0.5 Ma $(95 \% \mathrm{HPD}=0.9-0.2 \mathrm{Ma})$. The substitution rate estimated for Pimoa coxl was 0.0217 substitutions per lineage/million years $(95 \%$ HPD $=0.011-0.033)$, and for the ITS-2 was 0.006 $(95 \%$ HPD $=0.002-0.013)$. The basal split between Pimoa n. sp. and P. rupicola, was estimated to have occurred around 5.7 Ma $(\mathrm{HPD}=12-2 \mathrm{Ma})$. The origin of the extant diversity of each lineage was estimated approximately at $0.4 \mathrm{Ma}$ for both lineages $(\mathrm{HPD}=1-0.15$ and $\mathrm{HPD}=0.85-0.15 \mathrm{Ma}$,

450 for P. rupicola and Pimoa n. sp. respectively). 


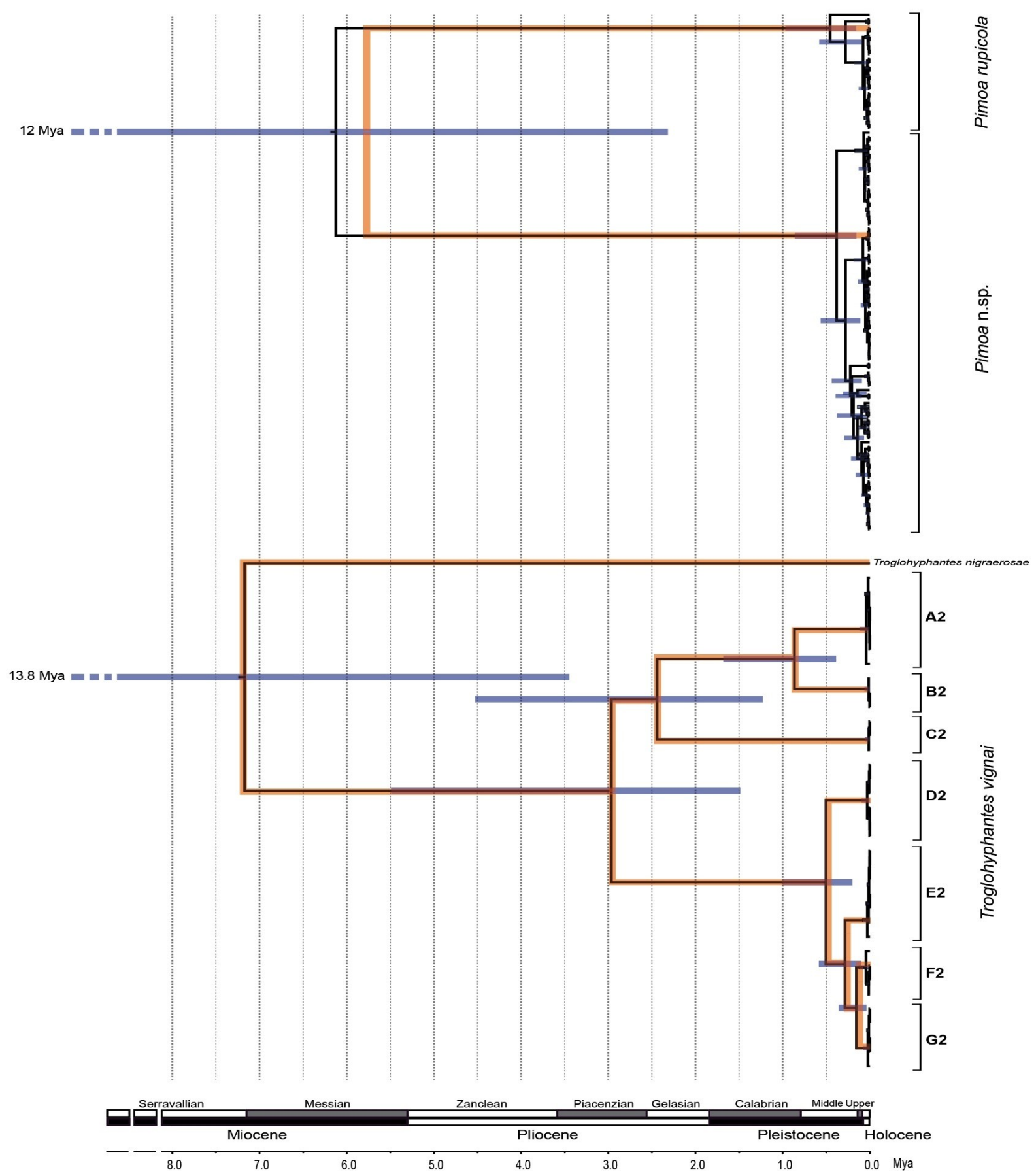

\section{Figure 4: timeframe of diversification.}

Chronograms obtained with the multispecies coalescent approach for the cox1 and ITS2 genes combined (orange topologies) and the coxl gene alone (black topologies). Grey node bars indicate the 95\% HPD confidence intervals of the divergence time (for sake of clarity, only those HPD referring to the coxl gene are shown). The common $\mathrm{x}$-axis is time in million years (Mya). 
We studied the climatic preference for the two Pimoa linages with PCA, using bioclimatic variables

475 (see Tab. 1 of Supplementary Materials 1). The bi-plot of scores for the first two axes of the PCA is shown in Fig. 5. The first two axes explained $86.2 \%$ of the variation in the data. The variance explained by other axis was negligible $(<1 \%$ each). In respect to the first two axes, the two species segregate into two distinct clusters. The first axis (eigenvalues $=12.28$; variance explained $=$ $62.0 \%$ ) mostly reflect a gradient of temperature. The second axis (eigenvalues $=4.79$; variance explained $=24.2 \%$ ) was positively correlated with variables reflecting diurnal and annual thermic excursion (Bio2, Bio4, Bio7) and anticorrelated with variables reflecting seasonal precipitation (Bio13, Bio16, Bio19). Although the first axis (PC1) explains most of the variance in the data, the localities of the two Pimoa species cluster in two groups according to the second axis (PC2), which combines bioclimatic variables referable to continentality. According to the original definition (see 485 Currey, 1974 for more details), continentality is intended as a measure of how the climate is affected by its remoteness from the sea. Specifically, the distance from water masses influences the climate in terms of higher seasonality (Bio4), increasing diurnal (Bio2) and annual (Bio7) temperature ranges, as well as decreasing precipitation in the coldest (Bio19) and wettest (Bio13 and 16) periods. In light of our results, Pimoa n. sp. occurs in areas characterized by higher continentality in respect to $P$. rupicola. 


\section{Manuscript to be reviewed}



Figure 5: Climatic segregation of the Pimoa lineages.

510 Bi-plot of Principal Component Analysis (PCA) scores for the first two axes based on 19 bioclimatic variables and altitude a.s.l. extracted for the localities of Pimoa n. sp. (purple dots) and Pimoa rupicola (green dots). For the explanation of the bioclimatic variables see table 1 in Supplementary Materials 1. 
The predictive performance of our bioclimatic models was fairly high both in Pimoa n. sp. (mean $\pm \mathrm{SD}$ AUC of the 20 runs $=0.845 \pm 0.053)$ and in P. rupicola $(0.908 \pm 0.089)$. Overall, the suitable areas predicted by the model were congruent with the known distribution of the two species, at least in the Western Alps and Apennines. Current predictions identified suitable areas for P. n. sp. around the medium mountain belt (500-1500 m a.s.1.) of the Central and Western Alps, from the Camonica valley (province of Bergamo) down to the margin between Cottian and Maritime Alps (Stura valley, province of Cuneo). In respect to the known distribution, the predicted rang of $P$. n. sp. extended northwards over the know limit of the species (see dotted line in Fig. 6a).

530 More suitable areas were also detected in the northern edge of the Tuscan Apennines (Fig. 6a). The suitable areas of P. rupicola corresponded to the southern border of the Western Alps, in the coastal belt that spreads from Côte d'Azur (SW France) to the Ligurian eastern coast and Tuscan Apennines (Italy). Additional suitable areas were also found in Tuscany, Lazio and Corsica. The projection of the distribution model to the environmental condition of the Last Glacial Maximum (LGM)

535 revealed that most of the current suitable areas were unsuitable in the LGM (Fig. 6b). Our threshold approach identified two main refugia for $P$. n. sp. (RF1) and P. rupicola (RF2 and RF3). All refugia corresponded to areas that were devoid from glaciers (in accordance with Ehlers, Gibbard \& Hughes, 2011). The RF1 extended outside the southern edge of the actual distribution of Pimoa n. sp., in the hills and plains surrounding roughly the Northern border of Maritime and Ligurian Alps.

540 RF2 corresponded to small areas along the French and Italian Riviera. RF3 extended over a wider geographic area in the Apennine, and in the northern part of the Corsica. 


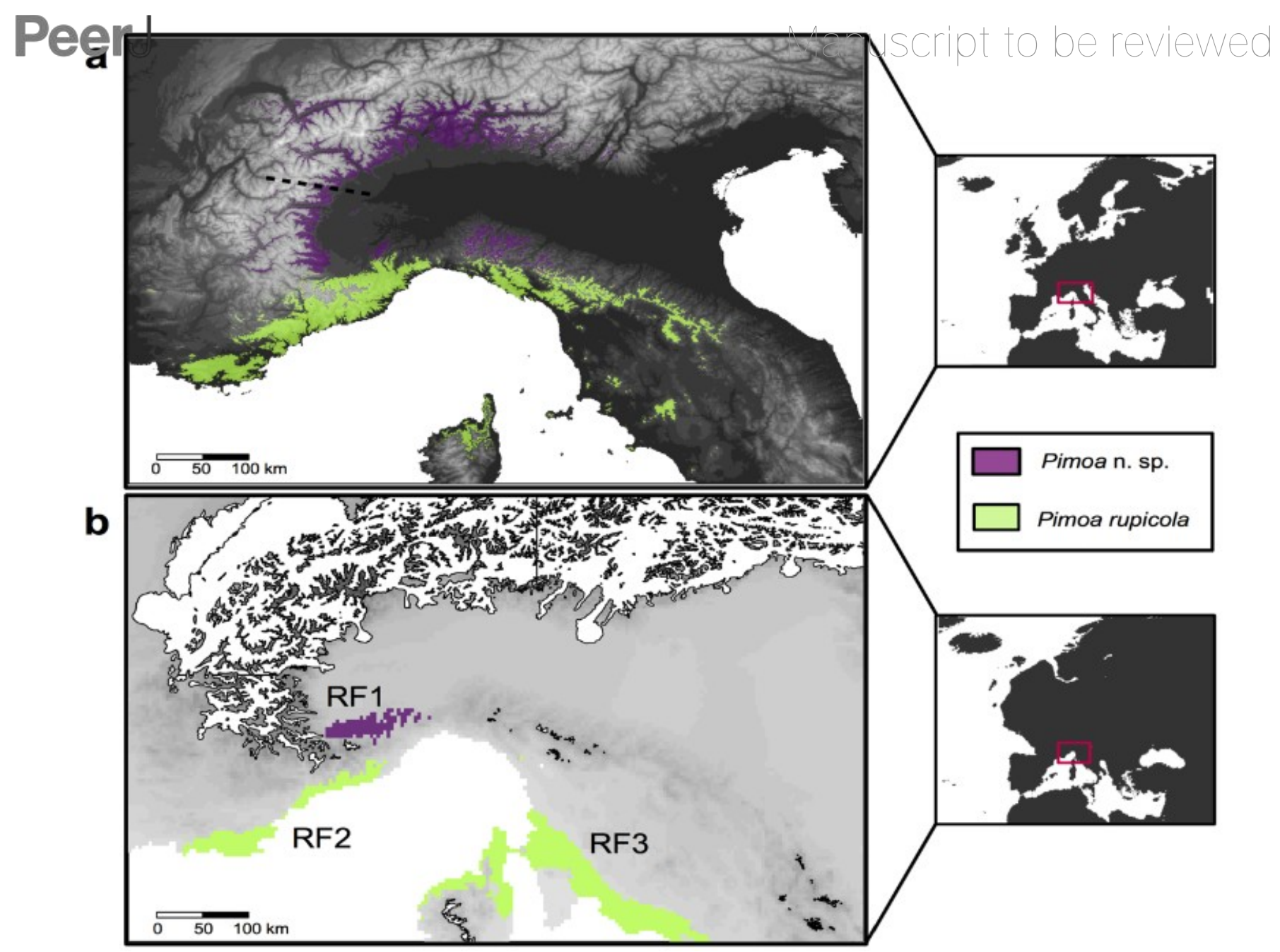

Figure 6. Current and past distribution of Pimoa lineages Maps of the predicted environmental suitability according to the ENMs fitted to the occurrence points for Pimoa n. sp. (purple surface) and P. rupicola (green surface), at the present climate (a) and during the Last Glacial Maximum (b). Potential Pleistocene refugia (RF1, RF2, RF3) were identified by combining the three GCMs climatic reconstructions and applying a threshold of 0.6. The northern limit of the known distribution of $P$. n. sp., corresponing to the Graian Alps (Isaia et al., 2011), is highlighted in the upper map with a dotted line. Limits of the ice cover in the Last Glacial Maximum (Ehlers, Gibbard $\&$ Hughes, 2011) are reported for Pleistocene projections (white shapes in the lower map). 
The history of two cave-dwelling spiders

The confounding effects of adaptation, biogeography and dispersal ability on the origin and the distribution patterns of cave organisms pose a stimulating challenge to biogeographers (Porter,

565 2007; Juan et al., 2010). According to Culver \& Pipan (2010), long term climatic changes can be claimed as the main factors that prompted invertebrate species to colonize the subterranean habitats. In this regards, the Miocene climatic transitions and the Pleistocene glaciations are regarded as the most important events. Here, by reconciling phylogeographic patterns and predictive ENMs, we provide support to this view, pointing out the Cenozoic climatic transitions has the most important

570 factors shaping the present day genetic diversity and the distribution range of our model species.

Although special caution should be exercised when considering time estimates based on molecular data, especially in the absence of fossil record (Hipsley, 2014), our results fits well with some of the major climatic event undergone in the Western Alps during the Cenozoic. Accordingly, the two Pimoa lineages and Troglohyphantes vignai originated from the Middle (Serravallian) to the Late

575 Miocene (Messinian), namely from 13 to 3.5 mya. More precisely, the isolation of $T$. vignai and $P$. rupicola from their northern sister groups (T. nigraerosae and P. n. sp.) dates back 7.2 and 5.7 mya, respectively. This time period approximately corresponds to the closure of the Gibraltar Strait and the onset of the so-called Messinian Salinity Crisis (MSC; after Ruggieri, Adams \& Ager, 1967). However, given the large confidence intervals around our time estimates ( $\sim 10$ million years), it is

580 difficult to draw precise conclusions about the event that exactly determined the split of the different lineages.

It is worth noticing that the onset of a climatic transition in the Middle Miocene, marked the decline of the last global climate optimum conditions, leading to a progressive deterioration of the dominant subtropical climatic conditions (Suc, 1984; Shevenell, Kennett \& Lea, 2004; Jimenez-Moreno et al.,

585 2010). It is arguable that in parallel to the slow climate deterioration and the increase of seasonality, isolation of Pimoa and Troglohyphantes occurred.

Being possibly pre-adapted to shallow moist humid habitats (Deeleman-Reinhold, 1978; Hormiga, 1994; Zhang \& Li, 2003; Wang et al., 2008 ), both species progressively colonized the subterranean habitat, most likely during the Pleistocene. Given their contrasting level of troglomorphism, it is 590 likely that the process began earlier in Troglohyphantes. 


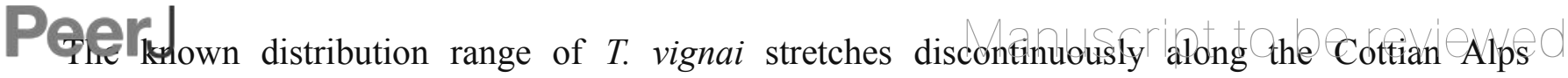
(Chisone, Po and Varaita valleys) down to Ligurian Alps (Valle Pesio). Conversely, the distribution of the northern sister group T. nigraerosae is adjacent southern Graian Alps (Isaia et al., 2011). The lack of shared haplotypes and the $F_{\mathrm{ST}}$ values close to 1 between the sampled localities of $T$. vignai indicates a strong isolation of the populations (Holsinger \& Weir, 2009). The same idea is further corroborated by the identification of each population as an independent coalescent lineage (ie. GYMC cluster). These results are in agreement with other studies on subterranean arachnids (Hedin 1997; Hedin \& Thomas 2010; Dixon \& Zigler 2011) that support the "caves as islands" scenario (sensu Snowman, Zigler \& Hedin, 2010), in which dispersal is virtually absent and the different 600 populations diverge in allopatry. Under such conditions, it seems likely the subterranean habitat acted as an evolutionary cul-de-sac (see Fišer, Blejec \& Trontelj, 2012) for T. vignai. According to our time estimates the diversification of extant $T$. vignai lineages (especially northern population) occurred approximately during the Pleistocene glaciations. In this respect, it is worth noting that subterranean localities inhabited by T. vignai lie at the periphery of the Pleistocene glaciers (Ehlers,

605 Gibbard \& Hughes, 2011; see also local glacial limits reconstructed in Motta, 2014). Because subterranean populations most likely cannot survive under the ice cover (Culver \& Pipan, 2010), we suggest that the present day distribution range of $T$. vignai is the shadow of a wider ancestral distribution. Populations inhabiting the northern valleys in the Cottian Alps (Germanasca and Chisone valleys; see Fig. 4), where the ice shield was more compact, provide further evidences of

610 the effect of Quaternary ice sheets.

In this area the distribution of $T$. vignai overlaps with the range of several hypogean species of Doderotrechus beetles (Carabidae, Trechini) (Giachino 1993; Giachino \& Vailati 1997; Casale \& Giachino 2008). The similarity of distribution of both groups is most likely the result of a similar response to glacial dynamics. Gaining further knowledge on the biogeography of other subterranean 615 species may provide further confirmation for the patterns here recovered.

In contrast with T. vignai, for which we did not detect any evidence of current population expansion, the topology of the chronogram obtained for Pimoa lineages hints at a recent expansion following a bottleneck (see Fig. 4). The putative population expansion in both lineages of Pimoa would fall within the Quaternary Glacial Cycles, between 2.8 and 2.5 Ma (Gibbard, Head \& Walker,

620 2010). The movement of glaciers as well as the continuous formation and melting of new ice sheets may have deeply affected the different populations, altering profoundly the local habitat suitability. Such transformations prompted either the migration of populations to more suitable areas at lower altitudes or latitudes or the local extinction of resident populations. Such scenario is congruent with 


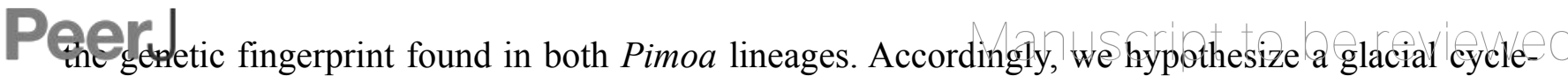

625 driven extinction of ancestral populations during cooler periods, followed by the expansion of populations which survived in climatic refugia during warmer periods. A similar pattern was observed in the Asian species P. clavata (Wang et al., 2008). The ENMs projected into the paleoclimatic reconstruction pointed out three putative areas devoid from glaciers that may have acted as glacial refugia for the surviving populations of each lineage (RF1-3; Fig. 6b). In the case of

630 P. n. sp., we detected one main macrorefugia (RF1) associated to the southernmost offshoots of the Alpine glacial masses. Notably, similar areas have also been classified as peripheral refugia for several Alpine plants, such as Phyteuma globulariifolium (Schönswetter et al., 2002) and Ranunculus glacialis (Schönswetter et al., 2003). For P. rupicola, potential macrorefugia (RF2 and 3) where located along the SW French coast (RF2) and the Tuscan coast (RF3), including the 635 northern part of Corsica. Despite the presence of P. rupicola in Tuscany is confirmed by literature records (Brignoli, 1971; Hormiga, 1994), recent investigation conducted by the authors did not confirm the present occurrence of the species in Corsica.

because of the larger spatial resolution of the LGM stacked rasters compared to the present day data (2.5 minutes versus 30 arc-seconds $(\sim 1 \mathrm{~km})$ ), it should be borne in mind that we may have not

640 detected small point-like microrefugia (sensu Rull, 2009) within the interior of the Pleistocene ice shield covering the Alps.

As suggested by the lower $F_{\mathrm{ST}}$ values compared to Troglohyphantes, the relatively fast recolonization of ice-free areas is probably the result of the more effective dispersal ability of Pimoa. In particular, the population expansion followed a south-north direction, leading to the 645 present distribution ranges of both lineages. Concerning $P$. n. sp., we additionally predict suitable areas up to the Central Alps. Given the continuity of the suitable habitats predicted by the ENM and the supposed high dispersal ability of Pimoa, we hypothesize an ongoing expansion of the populations northwards. Indeed, the occurrence of Pimoa in outer shaded and humid habitats such as beech forests and other broadleaved forests (Bertkau, 1890; Jackson, 1926; Thaler, 1976; Isaia et

650 al., 2014; Isaia, Paschetta \& Chiarle, 2015) provides empirical evidence of the existence of epigean dispersal. Because of the sex bias among the specimens collected in superficial habitats (Isaia et al., 2014; Isaia, Paschetta \& Chiarle, 2015) and the general trend observed for spiders (Foelix, 1996), gene flow appears mostly mediated by males.

It should be bore in mind, however, that in light of the relatively low sample-size and the potential 655 bias linked to the possible male-mediated dispersal, our coxl data (and the associated $F_{S T}$ results) 


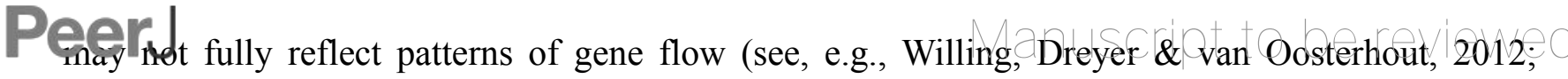
Davalos \& Russell, 2014). Since low sample size is known to impact this kind of estimations, caution should be exercised when interpreting the values of nucleotide and haplotype diversity calculated for each locality (e.g. Goodall-Copestake, Tarling \& Murphy, 2012). To minimize these potential bias, we left out from the calculation of the $F_{S T}$ populations consisting of less than three individuals. Nevertheless, it is worth noticing that during data exploration we obtained very similar patterns of gene flow when comparing coxl and ITS-2 results.

At present, the two lineages of Pimoa identified in this study show allopatric distributions (Fig. 6). $P$. n. sp. populations occur preferentially in areas characterized by higher continentality, seem to 665 tolerate cooler temperatures at higher altitudes and latitudes, as suggested by the results of the PCA (Fig. 5). On the other hand, Pimoa rupicola occurs in less continental areas, characterized by relatively small seasonal variations and high mean annual temperatures (i.e. Mediterranean climate). Similar complete niche partitioning between congeneric subterranean spiders has been reported elsewhere (Ribera, 1978; Gasparo \& Thaler, 2000; Mammola \& Isaia, 2014).

670 The application of ENM techniques has become a widespread practice to answer biogeographical and evolutionary questions (Franklin, 2009). In particular, ENM have been extensively used to identify Pleistocene refugia (e.g. Waltari et al., 2007; Rodriguez-Sanchez \& Arroyo, 2008; Peterson, 2009; Planas et al., 2014). In constructing our scenarios, we have adopted a conservative approach, as our goal was to generate predictions under different levels of uncertainty. Although we relied on

675 this approach, we are aware that ENMs have been rarely - and only recently - applied to study the hypogean ecosystems (see, e.g., Bryson et al., 2014; Camp et al., 2014; Naranjo, Moreno \& Martín, 2014). This is probably because, in first approximation, the link between the climatic variables (i.e. the external climate) and the subterranean habitat is not so straightforward. However, temperature of the underground compartment generally reflects the climatic regimen on the surface (Smithson,

680 1991; Badino, 2010). Although less intuitive, the regimen of rainfall plays an equally crucial role if not more important - in determining such conditions [see details in Badino (2004, 2010)].

\section{Overlooked diversity}

In light of our results, some consideration regarding the overlooked diversity of our model species can be drawn. Concerning T. vignai, in this study we have included specimens from eight different localities, including topotypical material and material of $T$. vignai sensu rupicapra. The low levels of genetic variability observed between the latter and the topotypic material of T. vignai (Fig. 2, p- 


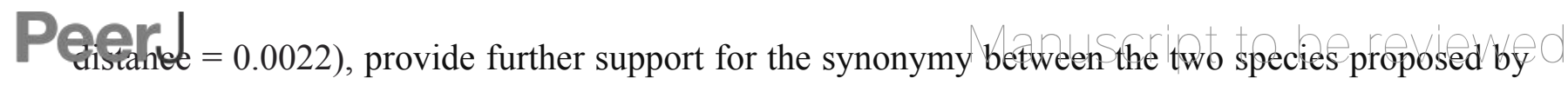
Pesarini (2001). Therefore specimens of $T$. vignai sensu rupicapra have to be regarded as a 690 population of T. vignai isolated in an area characterized by different climatic conditions (major Mediterranean influence). Such isolation could tentatively be related to the higher development of troglomorphism in T. vignai sensu rupicapra, as already observed by Brignoli (1971) and Isaia \& Pantini (2010). Moreover, climatic factors provide a further line of interpretation for the presence of two main lineages within T. vignai, corresponding to the northern and the southern clade (Fig. 1 and

695 2). Slight differences in the shape of the lamella significativa of the male palp could lead to consider the two lineage as candidate species (Vieites et al., 2009), however the genetic distance between the two lineages, is about half of the value observed in the two nominal species $T$. vignai and its northern sister group T. nigraerosae.

The genus Pimoa is represented worldwide by 28 species (World Spider Catalogue, 2015), many of

700 which have only been described recently (Xu \& Li, 2007, 2009; Trotta, 2009; Hormiga \& Lew, 2014). The application of molecular tools to investigate fine scale phylogeographic patterns in this group may uncover additional hidden diversity (Wang et al., 2008). It is generally accepted that species delimitation and eventually species description should be based on the integration of multiple lines of evidence (Padial et al., 2010). Here, we uncovered two deeply divergent genetic

705 lineages (Fig. 3, GYMC clusters with p-distance above 9\%), within Pimoa rupicola, which are further delimited both by genitalic morphology (Mammola et al., unpublished data) and different ecological requirements (Fig. 5).

\section{Conclusions}

710 Here, we have described the origin and the subsequent diversification of two species of spiders with contrasting levels of troglomorphism. We suggest that a different level of adaptation to subterranean life is an important factor to consider in the study of phylogeographic patterns. In particular, the major climatic events that occurred in the Alps during the Cenozoic determined from one side the complete isolation of pre-adapted subterranean species causing present day high population

715 structuring, and from the other, the obliteration of surface-dwelling populations, causing their extinction or the lack of genetic structure in present day populations.

The parallel study of populations of subterranean species, especially when showing different levels of adaptation and overlapping ranges of distribution, may disclose new ways to understand patterns of biological diversification. Future research may include new highly variable nuclear markers and 



beetles), to shed further light on the processes that shaped the present diversity of Alpine subterranean fauna.

\section{Acknowledgements}

We are indebted to Eli Mora, Leticia Bidegaray-Batista, Ana Riesgo, Sergio Taboada and Vanina Tonzo for their useful suggestions on the analysis and the interpretation of the results. SM would especially thank Paola Mazzuca for guiding him through the molecular lab protocols. We are grateful to Carola Ponzetto for proofreading a preliminary version of this manuscript and to to Irene Frigo for the help in creating the layout of figures 1, 2, 3 and 4. Finally, a very special thanks goes to all the friends and colleagues that helped us in the collecting (Mauro Paschetta, Elena Piano, Davide Giuliano, Alessandro Giresi and Giovanni Badino) and to Gustavo Hormiga for providing material of Pimoa edenticulata for DNA comparison.

\section{References}

Agnarsson I. 2010. The utility of ITS2 in spider phylogenetics: notes on prior work and an example from Anelosimus. The Journal of Arachnology 38:377-382.

730 Allegrucci G, Minasi GM, Sbordoni V. 1997. Patterns of gene flows and genetic structure in cave-dwelling crickets of the Tuscan endemic, Dolichopoda schiavazzii (Orthoptera, Raphiidophoridae). Heredity 78:665-673.

Arnò C, Lana E. 2005. Ragni cavernicoli del Piemonte e della Valle d'Aosta. Torino: "La Grafica Nuova".

Badino G. 2004. Clouds in caves. Speleogenesis and Evolution of Karst Aquifers 2:1-8.

Badino G. 2010. Underground meteorology. What's the weather underground? Acta Carsologica 39(3):427-448.

Barve N, Barve V, Jiménez-Valverde A, Lira-Noriega A, Maher SP, Peterson AT, Soberón J, Villalobos F. 2011. The crucial role of the accessible area in ecological niche modeling and species distribution modeling. Ecological Modeling 222:1810-1819.

Bertkau P. 1890. Arachniden gesammelt vom 12. November 1888 bis zum 10. Mai 1889 in San Remo von Prof. Dr Oskar Schneider 1-11.

Bidegaray-Batista L \& Arnedo MA. 2011. Gone with the plate: the opening of the western Mediterranean basin drove the diversification of ground-dweller spiders. BMC Evolutionary Biology 11:317. DOI: 10.1186/1471-2148-11-317

Bohonak AJ. 1999. Dispersal, gene flow and population structure. The quaterly review of biology 74(1):21-45. 
Borges PAV, Cardoso P, Amorim IR, Pereira F, Constância JP, Nunes JC, Barcelos P, Costa P, Gabriel R, Dapkevicius MDL. 2012. Volcanic caves: priorities for conserving the Azorean endemic troglobiont species. International Journal of Speleology 41(1):101-112. DOI: 10.5038/1827-806X.41.1.11

755 Botosaneanu L, Holsinger J. 1991. Some aspects concerning colonization of the subterranean realm - especially subterranean waters: a response to Rouch and Danielopol, 1987. Stygologia 6:11-39.

Brignoli PM. 1971. Note su ragni cavernicoli italiani (Araneae). Fragmenta entomologica 7(3):129-229.

760 Brignoli PM. 1972. Catalogo dei ragni cavernicoli italiani. Quaderni di Speleologia del Circolo Speleologico Romano 20:1-211.

Brignoli PM. 1985. Aggiunte e correzioni al «Catalogo dei Ragni cavernicoli italiani». Memorie del Museo civico di Storia naturale di Verona 2(4):51-64.

Britton T, Anderson CL, Jacquet D, Lundqvist S, Bremer K. 2007. Estimating divergence times in large phylogenetic trees. Systematic Biology 56:741-752.

Bryson RW (Jr), Prendini L, Savary WE, Pearman PB. 2014. Caves as microrefugia: Pleistocene phylogeography of the 770 troglophilic North American scorpion Pseudouroctonus reddelli. BMC Evolutionary Biology 14:9. DOI:10.1186/14712148-14-9.

Camp DA, Wooten JA, Jensen JB, Bartek DF. 2014. Role of temperature in determining relative abundance in cave twilight zones by two species of lungless salamander (family Plethodontidae). Canadian Journal of Zoology 92(2):119127. DOI: $10.1139 /$ cjz-2013-0178

Cardoso P. 2012. Diversity and community assembly patterns of epigean vs. troglobiont spiders in the Iberian Peninsula. International Journal of Speleology 41(1):83-94. DOI: 10.5038/1827-806X.41.1.9

780 Casale A, Giachino PM. 2008. Note sul genere Doderotrechus Vigna Taglianti, 1968, con descrizione di Doderotrechus ghilianii isaiai n. subsp. (Coleoptera, Carabidae). Rivista Piemontese di Storia Naturale 29:279-297.

Christiansen K. 1962. Proposition pour la classification des animaux cavernicoles. Spelunca 2:75-78.

Christman MC, Culver DC, Madden MK \& White D. 2005. Patterns of endemism of the eastern North American cave fauna. Journal of Biogeography 32:1441-1452.

Clement M, Snell Q, Walke P, Posada D, Crandall, K. 2002. TCS: estimating gene genealogies. Proceedings 16th International Parallel Distribution Process Symposium 2:184.

Culver DC, Pipan T. 2008. Superficial subterranean habitats - gateway to the subterranean realm? Journal of Cave and Karst Science 35:5-12.

Culver DC, Pipan T. 2009. The Biology of Caves and other Subterranean Habitats. Oxford: University Press.

Culver DC, Pipan T. 2010. Climate, abiotic factors, and the evolution of subterranean life. Acta Carsologica 39(3):39577.

Culver DC, Pipan T. 2014. Shallow Subterranean Habitats. Ecology, Evolution, and Conservation. Oxford: University 
Currey DR. 1974. Continentality of extratropical climates. Annals of the Association of American Geographers 64:268280.

Davalos LM \& Russell AL. 2014. Sex-biased dispersal produces high error rates in mitochondrial distance-based and tree-based species delimitation. Journal of Mammalogy 95(4):781-791.

Deeleman-Reinhold CL. 1978. Revision of the cave-dwelling and related spiders of the genus Troglohyphantes Joseph (Linyphiidae), with special reference to the jugoslav species. Opera Academia Scientiarum et Artium Slovenica (Classis IV) 23(6):1-221.

Dixon GB, Zigler KS. 2011. Cave-Obligate Biodiversity on the Campus of Sewanee: The University of the South, Franklin County, Tennessee. Southeastern Naturalist 10(2):251-266.

815 Drummond AJ, Suchard MA, Xie D, Rambaut A. 2012. Bayesian phylogenetics with BEAUti and the BEAST 1.7. Molecular Biology And Evolution 29:1969-1973. DOI: 10.1093/molbev/mss075.

Ehlers J, Gibbard PL, Hughes PD. (eds) 2011. Quaternary glaciations - extent and chronology. A closer look. Developments in Quaternary Science Vol. 15. Amsterdam: Elsvier.

Elith J, Graham H, Anderson P, Dudík M, Ferrier S, Guisan A, Hijmans J, Huettmann F, Leathwick R, Lehmann A, Li J, Lohmann G, Loiselle A, Manion G, Moritz C, Nakamura M, Nakazawa Y, Overton CM, Townsend PA, Phillips J, Richardson, K, Scachetti-Pereira, R, Schapire, E, Soberón, J, Williams, S, Wisz, S, Zimmermann, E. 2006. Novel methods improve prediction of species' distributions from occurrence data. Ecography 29:129-151. DOI: 10.1111/j.2006.0906-7590.04596.x

Excoffier L, Laval G, Schneider S. 2005. Arlequin ver. 3.0: an integrated software package for population genetics data analysis. Evolutionary Bioinformatics Online 1:47-50.

830 Ezard T, Fujisawa T, Barraclough T. 2014. splits: SPecies' LImits by Threshold Statistics. $R$ package version 1.0-19/r51, http://R-Forge.R-project.org/projects/splits/

Faille A, Ribera I, Deharveng L, Bourdeau C, Garney L, Quéinnec E, Deuve T. 2010. A molecular phylogeny shows the single origin of the Pyrenean subterranean Trechini ground beetles (Coleoptera: Carabidae). Molecular Phylogenetics and Evolution 54:97-106. DOI: 10.1016/j.ympev.2009.10.008.

Fišer C, Blejec A, Trontelj P. 2012. Niche-based mechanisms operating within extreme habitats: a case study of subterranean amphipod communities. Biology Letters 8(4):578-581. DOI: 10.1098/rsbl.2012.0125.

Foelix RF. 1996. Biology of Spiders (second edition). New York: Oxford University Press.

Folmer O, Black M, Hoeh W, Lutz R, Vrijenhoek R. 1994. DNA primers for amplification of mitochondrial cytochrome c oxidase subunit I from diverse metazoan invertebrates. Molecular Marine Biology and Biotechnoly 3:294-299.

845 Franklin J. 2009. Mapping species distributions: spatial inference and prediction. Cambridge: Cambridge University Press. 
Fujisawa T, Barraclough TG. 2013. Delimiting species using single-locus data and the Generalized Mixed Yule Coalescent (GMYC) approach: a revised method and evaluation on simulated data sets. Systematic Biology 65:707-724.

850

Gasparo F, Thaler K. 2000. I ragni cavernicoli del Venezia Giulia (Italia nord-orientale) (Arachnida, Araneae). Atti $e$ Memorie della Commissione Grotte “E. Boegan” 37:17-55.

Gentile G, Sbordoni V. 1998. Indirect methods to estimate gene flow in cave and surface populations of Androniscus dentiger (Isopoda : Oniscidea). Evolution 52(2):432-442.

Giachino PM. 1993. Canavesiella, nuovo genere dei Leptodirinae delle Alpi Occidentali, con 2 nuove specie (Coleoptera, Cholevidae). Bollettino del Museo Regionale di Scienze Naturali di Torino 11 (2):347-363.

Giachino PM, Vailati D. 1997. Nuovi dati su Archeoboldoria Ghidini, 1937, con descrizione di A. lanai (Coleoptera, Cholevidae, Leptodirinae). Rivista Piemontese di Storia Naturale 18:161-171.

Giachino PM, Vailati D. 2010. The subterranean environment. Hypogean life, concepts and collecting techniques. Verona: WBA Handbooks.

Gibbard PL, Head MJ, Walker MJC. 2010. Formal ratification of the Quaternary System/Period and the Pleistocene Series/Epoch with a base at 2.58 Ma. Journal of Quaternary Science 25:96-102.

Goodall-Copestake WP, Tarling GA \& Murphy EJ. 2012. On the comparison of population-level estimates of haplotype

and nucleotide diversity: a case study using the gene cox1 in animals. Heredity 109:50-56.

Hedin MC. 1997. Molecular phylogenetics at the population/species interface in cave spiders of the southern Appalachians (Araneae: Nesticidae: Nesticus). Molecular Biology and Evolution 14:309-324.

875 Hedin M, Thomas SM. 2010. Molecular systematics of Eastern North American phalangodidae (arachnida: opiliones: laniatores), demonstrating convergent morphological evolution in caves. Molecular Phylogenetic and Evolution 54: 107-121. DOI: 10.1016/j.ympev.2009.08.020

Heled J, Drummond AJ. 2010. Bayesian Inference of Species Trees from Multilocus Data. Molecular Biology and Evolution 27(3):570-580. DOI: 10.1093/molbev/msp274

Hipsley CA. 2014. Beyond fossil calibrations: realities of molecular clock practices in evolutionary biology. Frontiers in genetic 5:138. DOI: 10.3389/fgene.2014.00138

885 Hijmans RJ, Phillips S, Leathwick J, Elith J. 2014. dismo: Species distribution modeling. R package version 1.0-5. http://CRAN.R-project.org/package=dismo

Holsinger JR. 1988. Troglobites: the evolution of cave-dwelling organsims. American Scientist 76:146-153.

890 Holsinger KE, Weir BS. 2009. Genetics in geographically structured populations: defining, estimating and interpreting FST. Nature Reviews Genetics 10(9):639-650. DOI: 10.1038/nrg2611

Hormiga G. 1994. A revision and cladistic analysis of the spider family Pimoidae (Araneoidea: Araneae). Smithsonian 
Hormiga G, Lew S. 2014. A new American species of the spider genus Pimoa (Araneae, Pimoidae). Zootaxa 3827(1): 95-100. DOI: 10.11646/zootaxa.3827.1.9.

Isaia M, Pantini P. 2010. New data on the spider genus Troglohyphantes (Araneae, Linyphiidae) in the Italian Alps, with the description of a new species and a new synonymy. Zootaxa 2690:1-18. DOI: 10.1016/j.biocon.2011.08.021.

Isaia M, Paschetta M, Chiarle A. 2015. Annotated checklist of the spiders (Arachnida, Araneae) of the Site of Community Importance and Special Area of Conservation "Alpi Marittime" (NW Italy). Zoosystema 37(1):57-114. DOI: $10.5252 / \mathrm{z} 2015 \mathrm{n} 1 \mathrm{a} 4$

Isaia M, Paschetta M, Gobbi M, Zapparoli M, Chiarle A., Taglianti AV. 2014. Stand maturity affects positively grounddwelling arthropods in a protected beech forest. Annals of Forest Science. DOI: 10.1007/s13595-014-0441-x

Isaia M, Paschetta M, Lana E, Pantini P, Schőnhofer AL, Christian E, Badino G. 2011. Subterranean arachnids of the

Western Italian Alps (Arachnida: Araneae, Opiliones, Palpigradi, Pseudoscorpiones). Torino: Museo di Scienze Naturali, Monografie XLVII.

Jackson AR. 1926. A list of spiders found by Mr H. Donisthorpe at Bordighera in Northern Italy. Entomological Research 38:26-28.

Juan C, Guzik MT, Jaume D, Cooper SJB. 2010. Evolution in caves: Darwin's 'wrecks of ancient life' in the molecular era. Molecular Ecology 19:3865-3880. DOI: 10.1111/j.1365-294X.2010.04759.x.

Jeannel R. 1943. Les Fossiles vivants des Cavernes. Paris: Gallimard.

Juberthie C, Delay B., Bouillon M. 1980. Extension du milieu souterrain superficiel en zone non-calcaire: description d'un nouveau milieu et de son peuplement par les coleopteres troglobies. In: Evolution des coleopteres souterrains et endoges. Mémoires de Biospeologie 7:19-52.

Juberthie C, Delay B., Bouillon M. 1981. Sur l'existence du milieu souterrain superficiel en zone calcaire. In: Les entrees d'energie dans le karst et communications libres. Mémoires de Biospeologie 8:77-93.

Kane TC., Barr TC (jr), Badaracca WJ. 1992. Cave beetle genetics: geology and gene flow. Heredity 68:27-286.

930 Katoh K, Toh H. 2008. Recent developments in the MAFFT multiple sequence alignment program. Briefings in Bioinformatics 9:286-298.

Kearse M, Moir R, Wilson A, Stones-Havas S, Cheung M, Sturrock S, Buxton S, Cooper A, Markowitz S, Duran C, Thierer T, Ashton B, Mentjies P, Drummond A. 2012. Geneious Basic: an integrated and extendable desktop software platform for the organization and analysis of sequence data. Bioinformatics 28(12):1647-1649.

Lanfear R, Calcott B, Ho SYW, Guindon S. 2012. Partitionfinder: combined selection of partitioning schemes and substitution models for phylogenetic analyses. Molecular Biology and Evolution 29: 1695-1701. 


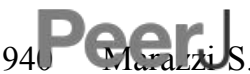

Alpino. Priuli \& Verlucca.

Mammola S, Isaia M. 2014. Niche differentiation in Meta bourneti and M. menardi (Araneae, Tetragnathidae) with notes on the life history. International Journal of Speleology 43(3):343-353. DOI: 10.5038/1827-806X.43.3.11

Motta M. 2014. The Definition of the Extension of Quaternary Glaciers within Alpine Valleys, and his Application to Study of Troglobites. EDIS - Publishid Institution of the University of Zilina 1:439-444.

Müller K. 2005. SeqState - primer design and sequence statistics for phylogenetic DNA data sets. Applied

Bioinformatics 4:65-69.

Naranjo M, Moreno ÁC, Martín S. 2014. ¿Dónde buscar troglobiontes? Ensayo de una cartografía predictiva con MaxEnt en Gran Canaria (islas Canarias). Arxius de Miscellània Zoològica 12:83-92.

Oaks JR. 2011. A time-calibrated species tree of Crocodylia reveals a recent radiation of the true crocodiles. Evolution 65:3285-3297.

Oksanen FJ, Blanchet G, Kindt R, Legendre P., Minchin PR, O'Hara RB, Simpson GL, Solymos P, Henry M, Stevens H, Wagner H. 2013. vegan: Community Ecology Package. $R$ package version 2.0-10. http://CRAN.Rproject.org/package $=$ vegan

Padial J, Miralles A, De la Riva I, Vences M. 2010. The integrative future of taxonomy. Frontiers in Zoology 7:16. DOI: $10.1186 / 1742-9994-7-16$

965 Peck SB. 1980. Climatic change and the evolution of cave invertebrates in the Grand Canyon, Arizona. National Speleological Society Bulletin 45:53-60.

Pesarini C. 2001. Note sui Troglohyphantes italiani, con descrizione di quattro nuove specie (Araneae, Linyphiidae). Atti della Società Italiana di Scienze Naturali e del Museo Civico di Storia Naturale di Milano 142(1):109-133.

970

Peterson AT. 2009. Phylogeography is not enough: the need for multiple lines of evidence. Frontiers in Biogeography $1: 19-25$.

Pfeifer B, Wittelsbuerger U, Ramos-Onsins SE, Lercher MJ. 2014. PopGenome: An Efficient Swiss Army Knife for Population Genomic Analyses in R. Molecular Biology and Evolution 31:1929-1936.

Phillips SJ, Anderson RP, Schapire RE. 2006. Maximum entropy modeling of species geographic distributions. Ecological Modelling 190:231-259.

980 Planas E, Saupe EE, Lima-Ribeiro MS, Peterson AT, Ribera C. 2014. Ecological niche and phylogeography elucidate complex biogeographic patterns in Loxosceles rufescens (Araneae, Sicariidae) in the Mediterranean Basin. BMC evolutionary biology 14: 195. DOI: 10.1186/s12862-014-0195-y

Porter ML. 2007. Subterranean biogeography: what have we learned from molecular techniques? Journal of Cave and

Karst Studies 69(1):179-186. 
R Development Core Team. 2013. R: A language and environment for statistical computing. Vienna: R Foundation for Statistical Computing.

990 Rambaut A, Suchard MA, Xie D, Drummond AJ. 2014. Tracer v1.6. Available at http://beast.bio.ed.ac.uk/Tracer (accessed 22 March 2015)

Ribera I, Fresneda J, Bucur R, Izquierdo A, Vogler AP, Salgado JM, Cieslak A, 2010. Ancient origin of a Western Mediterranean radiation of subterranean beetles. BMC Evolutionary Biology 10:29. DOI: 10.1186/1471-2148-10-29

Ribera C. 1978. Contribution à la Connaissance de la faune favernicole du nordest de 1'Espagne: le genre Meta. Proceedings of the 7th International Congress of Arachnology (Exeter, 1977), Symposium 2001 Society of London 42: 353-358.

Romero A. 2012. Caves as biological space. Polymath: An Interdisciplinary Arts and Sciences Journal 2(3):1-15.

Ronquist F, Teslenko M, van der Mark P, Ayres DL, Darling A, Höhna S, Larget B, Liu L, Suchard MA, Huelsenbeck JP. 2012. MrBayes 3.2: efficient Bayesian phylogenetic inference and model choice across a large model space. Systematic Biology 61:539-542. DOI: 10.1093/sysbio/sys029

Ruggieri G, Adams CJ, Ager DV. 1967. The Miocene and latter evolution of the Mediterranean Sea. Aspects of Tethyan Biogeography. London: Systematic Association Publication.

Rull V. 2009. Microrefugia. Journal of Biogeography 36:481-484. DOI: 10.1111/j.1365-2699.2008.02023.x

1010

Schönswetter P, Tribsch A, Barfuss M, Niklfeld N. 2002. Several Pleistocene refugia detected in the high alpine plant Phyteuma globulariifolium Sternb. \& Hoppe (Campanulaceae) in the European Alps. Molecular Ecology 11:2637-2647. DOI: 10.1046/j.1365-294X.2002.01651.x

1015 Schönswetter P, Paun O, Tribsch A, Niklfeld H. 2003. Out of the Alps: colonisation of the Arctic by East Alpine populations of Ranunculus glacialis (Ranunculaceae). Molecular Ecology 12:3373-3381. DOI: 10.1046/j.1365294X.2003.01984.x

Shevenell AE, Kennett JP, Lea DW. 2004. Middle Miocene southern ocean cooling and Antarctic cryosphere expansion. Science 305:1766-1770. DOI: 10.1126/science.1100061

Silvestro D, Michalak I, 2011. RaxmlGUI: a graphical front-end for RAxML. Organism Diversity and Evolution 12:335-337. DOI: $10.1007 / \mathrm{s} 13127-011-0056-0$

1025 Simmons MP, Ochoterema H. 2000. Gaps as Characters in Sequence-Based Phylogenetic Analyses. Systematic Biology 49(2):369-381.

Simon C, Frati F, Beckenbach A, Crespi B, Liu H, Flook P. 1994. Evolution, weighting, and phylogenetic utility of mitochondrial gene sequences and a compilation of conserved polymerase chain reaction primers. Annals of the 


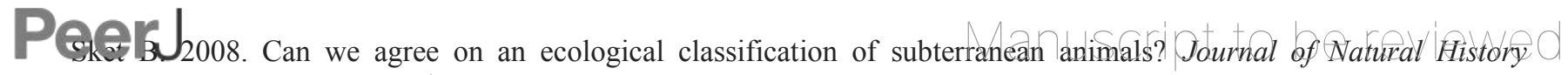
42:1549-1563. DOI: 10.1080/00222930801995762

1035 Smithers P. 2005. The early life history and dispersal of the cave spider Meta menardi (Latreille, 1804) (Araneae: Tetragnathidae). Bulletin of the British Arachnological Society 13(6):213-216.

Smithson A. 1991. Inter-relationships between cave and outside air temperatures. Theoretical and Applied Climatology 44:65-73.

1040

Snowman CV, Zigler KS, Hedin M. 2010. Caves as islands: mitochondrial phylogeography of the cave-obligate spider species Nesticus barri (araneae: Nesticidae). Journal of Arachnology 38:49-56. DOI: 10.338910.1636/A09-057.1

Stamatakis A. 2006. RaxML-VI-HPC: maximum likelihood-based phylogenetic analyses with thousands of taxa and mixed models. Bioinformatics 22:2688-2690. DOI: 10.1093/bioinformatics/btl446

Suc JP. 1984. Origin and evolution of the Mediterranean vegetation and climate in Europe. Nature 307:429-432.

Templeton AR, Crandall KA, Sing CF. 1992. A cladistic analysis of phenotypic associations with haplotypes inferred from restriction endonuclease mapping and DNA sequence data. III. Cladogram estimation. Genetics 132:619-633.

Thaler K. 1976. Two remarkable relict arachnids from northern Italy: Sabacon simoni Dresco (Opiliones: Ischyropsalididae), Louisfagea rupicola (Simon) (Araneae: Tetragnathidae). Bulletin of the British Arachnological Society 3:205-210.

Townsend TM, Mulcahy DG, Noonan BP, Sites JW, Kuczynski CA, Wiens JJ, Reeder TW. 2011. Phylogeny of iguanian lizards inferred from 29 nuclear loci, and a comparison of concatenated and species-tree approaches for an ancient, rapid radiation. Molecular Phylogeny and Evolution 61:263-380. DOI: 10.1016/j.ympev.2011.07.008.

1060 Trotta A. 2009. Pimoa thaleri, a new species of the genus Pimoa Chamberlin \& Ivie, 1943 from India (Araneae: Pimoidae). Contributions to Natural History 12:1403-1407.

Uéno S-I. 1987. The derivation of terrestrial cave animals. Zoological Science 4:593-606.

1065 Vidergar N, Toplak N \& Kuntner M. 2014. Streamlining DNA Barcoding Protocols: Automated DNA Extraction and a New cox1 Primer in Arachnid Systematics. PLoS ONE 9(11):e113030. DOI:10.1371/journal.pone.0113030

Vieites D, Wollenberg K, Andreone F, Köhler J, Glaw F, Vences M. 2009. Vast underestimation of Madagascar's biodiversity evidenced by an integrative amphibian inventory. Proceedings of the National Academy of Sciences $1070 \quad 106(20): 8267$.

Waltari E, Hijmans RJ, Peterson AT, Nyári ÁS, Perkins SL, Guralnik RP. 2007. Locating Pleistocene Refugia: Comparing Phylogeographic and Ecological Niche Model Predictions. PLoS ONE 2(7):e563. DOI: 10.1371/journal.pone.0000563

Wang Q, Li S, Wang R \& Parquin P. 2008. Phylogeographic analysis of Pimoidae (Arachnida: Araneae) inferred from mitochondrial cytochrome c oxidase subunit I and nuclear 28S rRNA gene regions. Journal of Zoological Systematics 
1080 White TJ, Bruns T, Lee S, Taylor J. 1990. Amplification and direct sequencing of fungal ribosomal RNA genes for phylogenetics. In: PCR Protocols: a guide to methods and applications. New York: Academic Press.

Willing E-M, Dreyer C, van Oosterhout C. 2012. Estimates of genetic differentiation measured by FST do not necessarily require large sample sizes when using many SNP markers. PLoS ONE 7(8):e42649. DOI: 10.1371/journal.pone.0042649

1085

World Spider Catalog (2015). World Spider Catalog. Natural History Museum Bern, available at http://wsc.nmbe.ch (Accessed 27 june 2015)

$1090 \mathrm{Xu}$ X, Li SQ. 2007. Taxonomic study of the spider family Pimoidae (Arachnida: Araneae) from China. Zoological Studies 46: 483-502.

Xu X, Li SQ. 2009. Three new pimoid spiders from Sichuan Province, China (Araneae: Pimoidae). Zootaxa 2298:5563.

Zhang Y, Li S.. 2013.Ancient lineage, young troglobites: recent colonization of caves by Nesticella spiders. BMC Evolutionary Biology 13:183. DOI: 10.1186/1471-2148-13-183 